
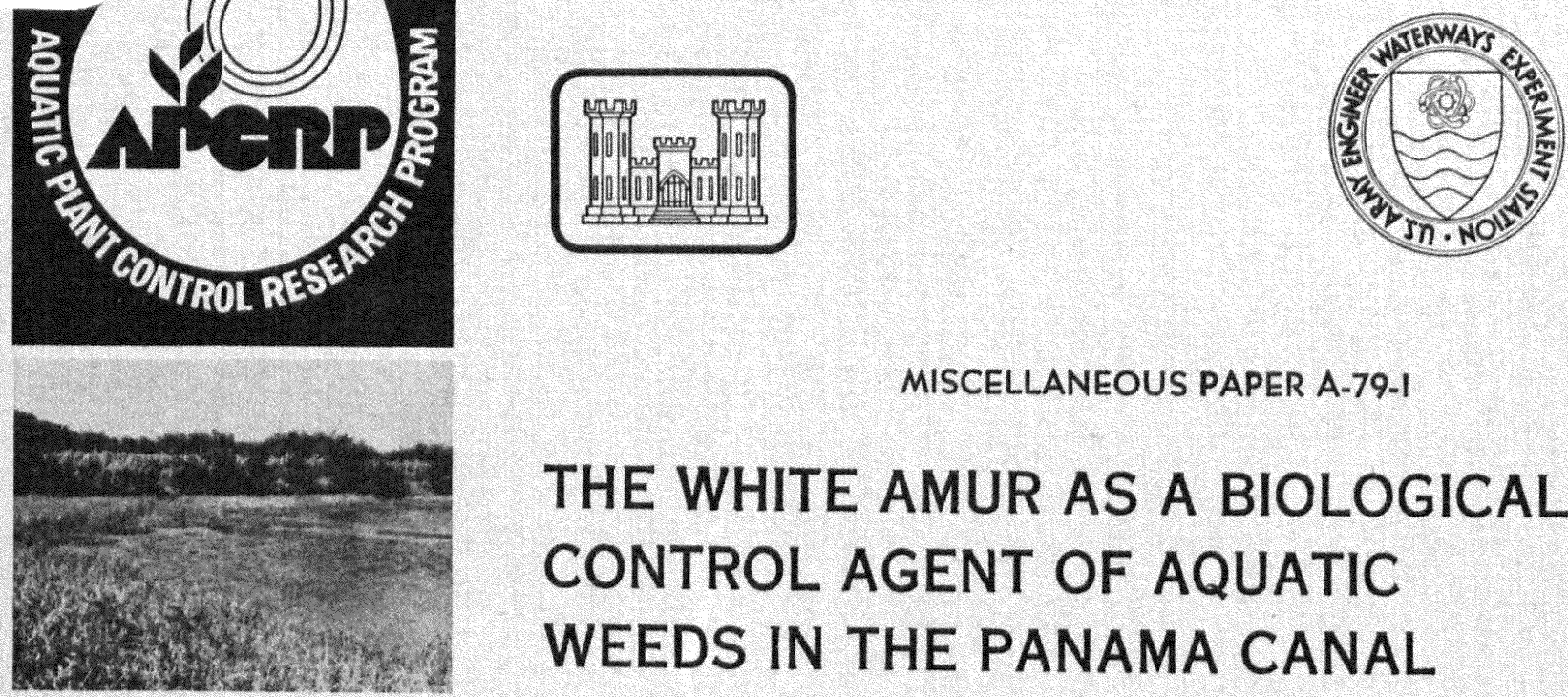

\title{
THE WHITE AMUR AS A BIOLOGICAL CONTROL AGENT OF AQUATIC WEEDS IN THE PANAMA CANAL
}

\author{
by Phillip E. Custer, Francis D. Halverson \\ James M. Malone, Cesar Von Chong \\ Panama Canal Company \\ Balboa Heights, Canal Zone \\ and Russell F. Theriot \\ Environmental Laboratory \\ U. S. Army Engineer Waterways Experiment Station \\ P. O. Box 631, Vicksburg, Miss. 39180
}

\section{April 1979 \\ Final Report}

Approved For Public Release; Distribution Unlimited

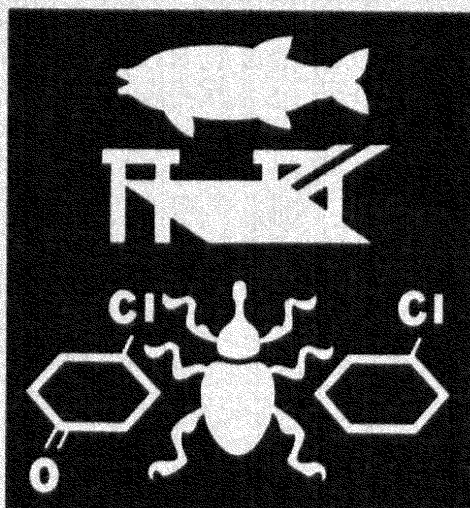

us

\author{
Garaer Banch \\ TECHWICAL WTFORMATION CENTER \\ ARMY ENGINEER WATERWAYS EXPERIMENT STATION \\ VICKSBURG. MISSISSIPPI \\ Prepared for Panama Canal Company \\ Balboa Heights, Canal Zone
}




\begin{tabular}{|c|c|}
\hline $\begin{array}{l}\text { REPORT DOCUMENTATION PAGE } \\
\end{array}$ & $\begin{array}{c}\text { READ INSTRUCTIONS } \\
\text { FEFORE COMPLETING FORM }\end{array}$ \\
\hline $\begin{array}{l}\text { 1. REPORT NUMBER } \\
\text { Miscellaneous Paper A-T9-1 }\end{array}$ & 3. RECIPIENT'S CATALOG NUMBER \\
\hline $\begin{array}{l}\text { 4. TITLE (nd Subitio) } \\
\text { THE WHITE AMUR AS A BIOLOGICAL CONTROL AGENT CF } \\
\text { AQUATIC WEEDS IN THE PAIJAMA CANAL }\end{array}$ & $\begin{array}{l}\text { 5. TYPE OF REPORT \& PERIOD COVERED } \\
\text { Final report }\end{array}$ \\
\hline & 6. PERFORMING ORG. REPORT NUMBER \\
\hline $\begin{array}{ll}\text { AUTHOR(o) } & \\
\text { Phillip E. Custer } & \text { Cesar Von Chong } \\
\text { Francis D. Halverson } & \text { Russell F. Theriot } \\
\text { James M. Malone } & \\
\end{array}$ & Q. CONTRACT OR GRANT NUMBER(A) \\
\hline $\begin{array}{l}\text { 9. PERFORMING ORGANIZATION NAME AND ADORESS } \\
\text { Panama Canal Company, Balboa Heights, Canal Zone } \\
\text { and } \\
\text { U. S. Army Engineer Waterways Experiment Station } \\
\text { Environmental Laboratory } \\
\text { P. O. Box } 631 \text {, Vicksburg, Miss. } 39180\end{array}$ & $\begin{array}{l}\text { 12. REPORT DATE } \\
\text { April } 1979\end{array}$ \\
\hline $\begin{array}{l}\text { 11. CONTROLLING OFFICE NAME AND ADDRESS } \\
\text { Panama Canal Company } \\
\text { Balboa Heights, Canal Zone }\end{array}$ & $\begin{array}{l}\text { 13. NUMBER OF PAGES } \\
35 \\
\text { 15. SECURITY CLASS. (ol thlo ropore) } \\
\text { Unclassified }\end{array}$ \\
\hline 14. MONITORING AGENCY NAME A ADDRESS(II dillerent fmen Conerolline OIIICo) & $\begin{array}{l}\text { 15a. DECLASSIFICATION/DOWNGRADING } \\
\text { SCHEDULE }\end{array}$ \\
\hline
\end{tabular}

16. DISTRIBUTION STATEMENT (ot thio Roport)

Approved for public release; distribution unlimited.

17. DISTRIBUTION STATEMENT (of the abotrect entered in Block 20, $l$ diltorent trom Roport)

10. SUPPLEMENTARY NOTES

19. KEY WOROS (Continue on reverce aide If neccecery and ldentlly by block numher)

Aquatic plant control .. Iydrilla

Aquatic weeds Panama Canal

Fishes Weed control

Gatun Lake. White amur

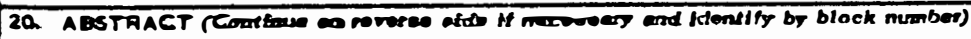

The Panama Canal hos been plagued with both floating and submerged aquatic weeds since its opening. Although more and more money has been spent on herbicides over the years, tine weed problem has increased. In Febmuary 1978, the Panama Canal Company introduced the white amur fish, Ctenopharyngodon idella (Val.), as a biological tool to contrcl the submereed macrophyte, hydrilla, to Gatun Lake, the large freshwater reservoir through which the majority of the 


\section{ABSTRACT (Continued).}

length of the Canal passes. Ninety percent of the first shipment of fish $(125,000)$ were estimated to have died due to the rapid change from cold Arkansas water temperatures to the warm tropical waters of Gatun Lake. A series of tests was conducted to determine tempering rates of the fish with temperature, dissolved oxygen level, and time as the variables. Various experiments with themical additives in the tempering water such as salt and quinaldine were also conducted. Based upon the tests, a tempering facility to acclimate a second fish shipment was constructed which circulated chilled lake water through a large fish holding tank for a period of 2 days during which time the temperature was gradually elevated and salt and antibiotics were added to the water. After tempering, the fish were successfully stocked in isolated arms of the lake using a helicopter for transportation. A third shipment of fish $(177,000)$ was delivered in August 1978 to replace fish lost from the first shipment. Fish were tranquilized with quinaldine prior to shipment from Arkansas. Dissolved oxygen was regulated in flight to approximately that of the lake. Fish were released directly into the grow-out areas resulting in less than 1 percent mortality. Fish from the first two shipments were released from the grow-out areas into Gatun Lake in August 1978 after attaining an average weight of $1 \mathrm{~kg}$. The Panama Canal Company plans to monitor the effect of the fish on the hydrilla infestation with annual infrared aerial photography and to initiate an annual white amur stocking program in FY 1981. 
The study described in this report was sponsored by the Panama Canal Company (PCC), Balboa Heights, Canal Zone, and was a cooperative effort of the PCC and the Corps of Engineers' Aquatic Plant Control Research Program (APCRP). The work was initiated in August 1977 under the general supervision of Mr. W. G. Shockley, Chief, Mobility and Environmental Systems Laboratory (MESL) of the U. S. Army Engineer Waterways Experiment Station (WES), Vicksburg, Miss., and Mr. B. O. Benn, Chief, Environmental Systems Division (ESD), MESL. The project was under the direct supervision of Mr. J. L. Decell, Program Manager, APCRP, at WES, and LTC Phillip E. Custer, CE, in the Canal Zone.

The work was performed by Mr. R. F. Theriot and Dr. D. R. Sanders of WES; LTC Custer and Messrs. Cesar Von Chong, Francis D. Halverson, and George Bouche of PCC; and J. M. Malone of Malone and Son Enterprises, Lonoke, Ark. This report was prepared by LTC Custer and Messrs. Halverson, Malone, Von Chong, and Theriot.

The APCRP and the ESD are now part of the recently organized Environmental Laboratory of which Dr. John Harrison is Chief.

Director of WES during the conduct of this study and preparation of the report was COL John L. Cannon, CE. Technical Director was Mr. F. R. Brown. 


\section{Contents}

Page

Preface ....................... 1

Conversion Factors, U. S. Customary to Metric (SI)

Units of Measurement ............. 3

Introduction ................... 4

Considerations Prior to Stocking of White Amur . . . . . . 6

The First Fish Delivery . . . . . . . . . . . . . . 9

Examining the problem .............. 11

Test conclusions ................... 12

The Successful Second Delivery ............. 13

The Third Fish Shipment . . . . . . . . . . . 17

Release of the Fish to Gatun Lake . . . . . . . . . . 21

Plates 1-13 
U. S. customary units of measurement used in this report can be converted to metric (SI) units as follows:

Multiply
acres (U. S. survey)
cubic feet
feet
inches
miles (U. S. statute)
pounds (mass)
pounds (mass) per
cubic foot
tons (2000 lb mass)
per acre

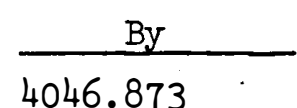

0.02831685

0.3048

2.54

1.609344

0.45359237

16.01846

0.00022417
To Obtain

square metres

cubic metres

metres

centimetres

kilometres

kilograms

kilograms per cubic metre

kilograms per square metre 
THE WHITE AMUR AS A BIOLOGICAL CONTROL AGENT

OF AQUATIC WEEDS IN THE PANAMA CANAL

\section{Introduction}

1. About two thirds of the length of the Panama Canal consists of a ship channel passing through a 40,000-ha freshwater reservoir $25 \mathrm{~m}$ above sea level. This reservoir, Gatun Lake, stretches from Pedro Miguel Locks on the Pacific side of the Isthmus to the Gatun Locks on the Atlantic side.

2. Over the years since the Canal was opened, aquatic plants have been a constant maintenance problem in Gatun Lake. Although hyacinths are the most troublesome aquatic, the increasing spread of the rooted plant hydrilla, Hydrilla verticillata (Royle), seriously blocks many channels which are traversed to maintain navigational aids (Figure 1). In addition, the infestation of this plant has rendered many recreation areas unfit for use and has increased the threat of mosquito-transmitted diseases by providing breeding grounds for the insects.

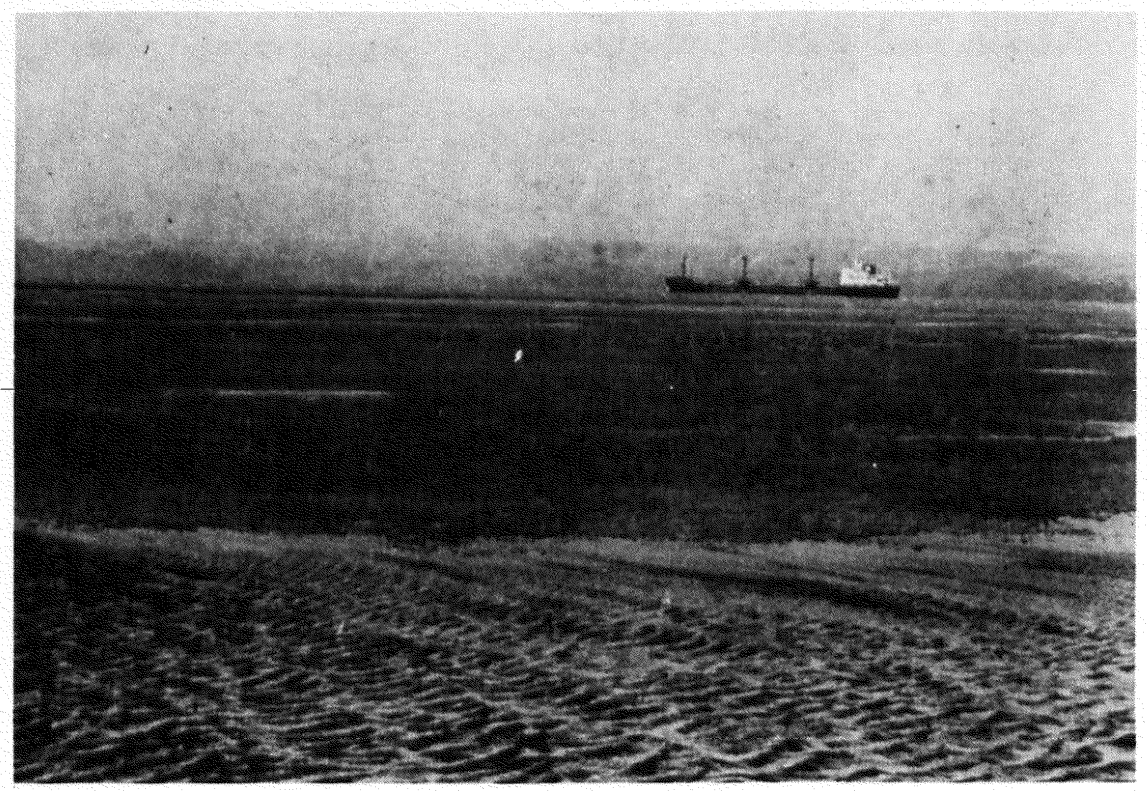

Figure 1. Hydrilla infestation in Gatun Lake. A ship may be seen in the Canal channel in the background 
3. While the Panama Canal Company has had aquatic plant control programs since construction days, it became apparent 2 years ago that, even though the Company was spending more and more money each year on aquatic plant control, the infestation of these pest plants was increasing at an alarming rate. This fact, coupled with cutbacks of some control activities in order to achieve costs savings in 1975, has compounded the problem.

4. During August 1976, the Company began investigating the introduction of the white amur fish, Ctenopharyngodon idella (Val.), into Gatun Lake as a biological control agent for submerged aquatic vegetation. At the request of the Panama Canal Company, representatives of the U. S. Army Engineer Waterways Experiment Station (WES), Vicksburg, Miss., visited the Canal Zone in November 1976 to advise Panama Canal Company officials on new methods of aquatic plant control. Based upon advice from WES personnel, a study was undertaken to determine the feasibility for use of the white amur. A technical steering committee was formed consisting of representatives of the various elements of Company management that would be involved. Mr. William Bailey, a fish biologist with the Arkansas Game and Fish Commission and a recognized expert on the white amur, was employed as a consultant.

5. WES suggested three alternatives for obtaining the fish, if the Company were to use them:

a. Spawn the fish in the Canal Zone, raise them to $0.5-\mathrm{kg}$ size, then stock them in the lake.

b. Buy fingerling fish from commercial fish farms in the U. S., raise them to $0.5-\mathrm{kg}$ size, then stock them.

c. Buy 0.5-kg. fish in the U. S., transport them to the Canal Zone, then stock them.

After considering the three alternatives, the steering committee, with inputs from Mr. Bailey, decided that buying fingerling fish in the U. $S$. and raising them to stocker size in the Canal Zone would be the least costly alternative and offered the greatest chance for success. Spawning the fish in the Canal Zone would have been too expensive and technically risky, and the logistics of transporting $0.5-\mathrm{kg}$ fish would have been overwhelming. 
6. Several issues had to be resolved prior to stocking the white amur. Two of the most important were:

a. - How many fish should be stocked?

b. What environmental impact would they have on the Panama Canal ecosystem?

WES was asked to help answer these questions. It was decided that the stocking rate model (Plate I) being tested in WES' Large-Scale Operations Management Test of the white amur in Lake Conway, Florida, would be used to determine the stocking rate.

7. Several characteristics of Gatun Lake had to be determined first for input to the model. Much needed information was readily available, such as total area and average depth; however, a major unknown was total submersed aquatic plant biomass. To determine this, the Panama Canal Company contracted with the Panamanian Government to aerially photograph the entire surface area of Gatun Lake using color infrared film. Submersed vegetation shows up very well on infrared film to approximately $5 \mathrm{ft}$ below the surface, and this procedure has been used successfully on other bodies of water in the past.. The developed film of Gatun Lake was sent to WES to be analyzed. It was determined that there were 11,600 acres of submersed vegetation in the lake (Plate 2). In order to determine the vegetation biomass, representative samples were taken from seven sampling locations which had previously been selected. Three vegetation samples were taken from the surface at each of the seven sites. A $0.5-\mathrm{m}^{2}$ quadrant was l'aid on the surface, and the vegetation contained within was clipped $0.5 \mathrm{~m}$ below the surface. . The samples were then allowed to drain for 2 minutes to remove excess water, and weighed to the nearest $0.1 \mathrm{lb}$.

8. A basic assumption used in calculating the total biomass of hydrilla was that, in areas $5 \mathrm{ft}$ and deeper, approximately 50 percent

A table of factors for converting U. S. customary units of measurement to metric (SI) units is presented on page 3. 
of the total hydrilla biomass would occur in the upper $0.5 \mathrm{~m}$. This was based on unpublished data collected from a mechanical harvesting operation in Orange Lake, Florida, and reinforced by conversations with Dr. Bill Haller of the University of Florida. Assuming this relationship, the hydrilla biomass was calculated to be $0.12 \mathrm{lb} / \mathrm{ft}^{3}$. At Gatun Lake's estimated average depth of $11 \mathrm{ft}$, this resulted in an average density of 29 tons/acre.

9. The biomass data and the other required parameters were used as input to the model with several different stocking rates for predictions of biomass of hydrilla and growth rate and mortality of the white amur (Plates 3-5).

10. The Panama Canal Company opted for a 20 fish/acre stocking rate (this refers to the 11,600 infested acres as determined from aerial photographs) or a total of 232,000 white amur. (For additional information concerning the stocking rate model, refer to WES document entitled, "National Briefing on the White Amur Research Project, Lake Conway, Florida,". and WES Instruction Report A-77-1 entitled, "Test Plan for the Large-Scale Operations Management Test of the Use of the White Amur to Control Aquatic Plants.")

11. Since the Panama Canal Company is an agency of the Federal Government, one of the major management considerations mandated by law was determining potential environmental effects of the project. Ecology Consultants, Inc., of Fort Collins, Colo., was employed to prepare a draft environmental impact statement (EIS) on the introduction of the fish into Canal Zone waters. Ecology Consultants, Inc., delivered the first draft to the Company in July 1977, and a final draft was published and sent out for comment on 17 August. A public hearing was held on 30 September, and by early November all comments on the final draft had been received by the Company. The final EIS was published on 16 December 1977. It is believed that this document is the first EIS prepared on the white amur fish.

12. Meanwhile, the white amur steering committee was developing plans for providing the necessary facilities and logistical support for the fish during the grow-out period. Three areas of Gatun Lake were 
selected as grow-out ponds (Plate 6). The first, Lake Calamito, was a 20-ha backwater separated from Gatun by a railroad fill and connected to it by a 6- by 6-m concrete arched culvert, $36.5 \mathrm{~m}$ long. This pond was prepared by treatment with rotenone to kill predator fish species and by installing a $0.6-\mathrm{cm}-s q u a r e$ mesh screen structure over the end of the culvert to prevent white amur from escaping it. The screen also served to keep predator fish species out. The second and third ponds, 12 and 43 ha in area, respectively, were isolated from Gatun Lake by earthen embankments with screened, l-m-diam pipes through them to allow free passage of water and keep the white amur in and predators out. These ponds were also treated with the same rotenone concentration as the first.

13. During most of the year, tropical rains drench the Isthmus of Panama, and large amounts of floating debris and severe currents flow out of the many tributaries to Gatun Lake. Because of this phenomenon, Canal officials were concerned that the screens over the culverts or the earthen dams which blocked the grow-out ponds might fail during the rainy season. The annual dry season extends from early January until late April or early May. The dry season was selected as the period of grow-out for the fish to minimize potential loss through screen or dam failures. The problem with this time table was that the white amur can be spawned artificially only in late May or early June. In order to provide fingeriing fish in January, the fish had to be ordered in May, spawned in more than sufficient numbers, and crowded into ponds to such an extent that their growth would be minimized over the 7-month period from June to January.

14. A contract to supply 250,000 fish was signed with J. M. Malone and Son Enterprises, Sea Ranch, Inc., and Leon Hill Catfish Hatchery, as a joint venture on 6 June 1977. All three suppliers operate fish farms in central Arkansas. Each of the partners in the joint venture was to supply a third of the required fish.

15. The sheer magnitude of shipping a quarter of a million fish from Arkansas to the Canal Zone was one problem that had to be overcome. Commercial air shipment in oxygenated bags was initially considered, but the number of boxes and volume of cargo for such an operation presented 
problems for the fish suppliers, the commercial carrier, and the Canal Company. It was finally decided to ship the fish in two increments of 125,000 fish each in a commercial fish transport truck aboard an Air Force C-130 cargo aircraft. The drive-on/drive-off feature of the large aircraft enabled the entire operation from loading in Arkansas to unloading in the Canal Zone to be accomplished in less than 24 hours. There was some concern that, if the fish had to remain in the truck longer, the build up of ammonia and carbon dioxide would be detrimental. To maintain the required dissolved oxygen (D.O.) level in the fish tanks during transportation, a liquid oxygen bottle was mounted on the rear of the truck bed and gaseous oxygen was bubbled into each tank through a pipe grid on its bottom.

\section{The First Fish Delivery}

16. The first shipment of 125,000 white amur fingerlings was made on 13 February 1978. The fish transport truck was driven from Lonoke, Ark., to Little Rock Air Force Base, then loaded on board the C-130 aircraft and flown to Howard Air Force Base in the Canal Zone (Figure 2). After the fish arrived, the truck was driven to Calamito Lake, the second largest of the three grow-out ponds, and the acclimation period was started in the transport tanks by mixing lake water at $28^{\circ} \mathrm{C}$ with the water in the tanks at $2^{\circ} \mathrm{C}$ (Figure 3 ). The transport truck had 16 tanks, each with a 380-litre capacity. The tanks had D.0. levels in excess of $10 \mathrm{mg} / \mathrm{l}$, while lake conditions varied between 3 and $5 \mathrm{mg} / \mathrm{l}$ depending on location and depth.

17. The length of acclimation for the 16 tanks varied from 4 to 8 hours. The temperatures of the tanks and lake were equalized to within $1^{\circ} \mathrm{C}$ when fish were released into the lake. Immediately upon entering the water, most of the fish went into severe shock and began swimming erratically and jumping out of the water. Within seconds they sank to the bottom ( 2 to $3 \mathrm{~m}$ ) where they remained immobilized. The bottom sediment and lower oxygen levels coupled to bring about their death. Approximately 70 percent of the fingerlings of the first shipment were 


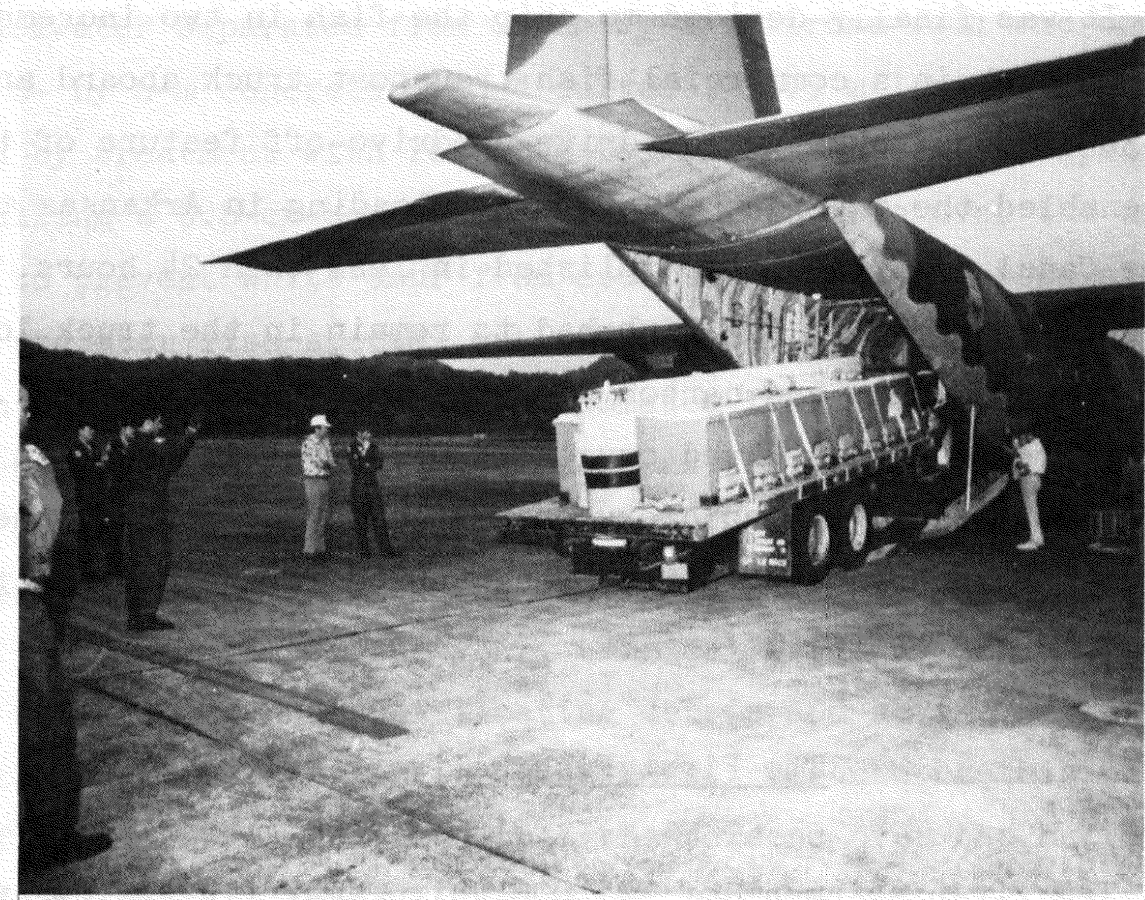

Figure 2. Unloading the fish transport truck from the Air Force C-130 at Howard Air Force Base, Canal Zone

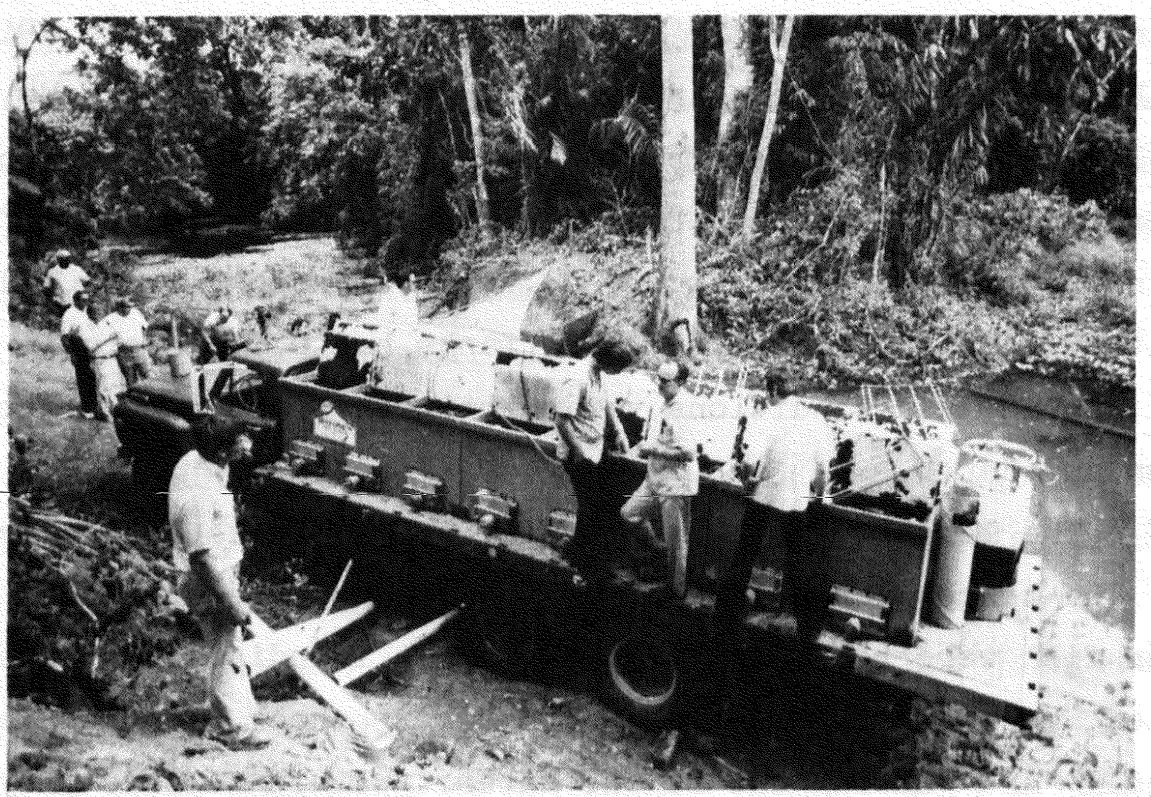

Figure 3. Temperature tempering at the edge of Lake Calamito with the first shipment of fish. This method proved to be unsuccessful because the temperature rise could not accurately be controlled and the fish could not be left in the truck long enough 
introduced into Lake Calamito, while the remaining 30 percent were placed in Dump 4-1/2 (see Plate 6). The same reaction of the fish was observed at Dump 4-1/2. An estimated 90 percent of the fingerlings in the first shipment died. Examination of the gills of live fish transferred at Dump $4-1 / 2$ from $25.6^{\circ} \mathrm{C}$ water to water with a temperature of $27.2^{\circ} \mathrm{C}$ showed discoloration 45 seconds after transfer. This reflects a metabolic problem beyond shock, possibly a breakdown in the ability of hemoglobin to transfer oxygen.

Examining the problem

18. Because of the high mortality experienced during the first fish shipment, temperature acclimation tests were conducted between 23 February and 3 March 1978. These tests were designed to determine a method for acclimating the second shipment of fish prior to putting them into the Gatun Lake rearing ponds. Approximately 1200 5- to 7-cmlong fingerlings were air-freighted to the Canal Zone in oxygenated bags. The fish arrived on the evening of 22 February 1978 and were placed in an ice storage room with a temperature of approximately $4^{\circ} \mathrm{C}$ during the period of tests. Test objectives were to:

a. Determine any latent effects from rotenone (applied 6 weeks earlier in the water of the rearing ponds).

b. Determine the effects of D.O. levels on survival.

c. Determine the effects of temperature and temperature change rates.on survival.

d. Devise a procedure for tempering the fish in the second shipment successfully.

19. Seventeen tests were performed in which D.0., rate of temperature change, and the effect of salt $(\mathrm{NaCl})$ and quinaldine were studied. Curves depicting parameter variations in the seventeen tests and thereactions of the fish are shown in Plates 7-ll.

20. The first two of these tests involved the effects of rapid temperature changes and dissolved oxygen level changes on the fish. Varying results were obtained in both tests. Two similar tests were conducted to determine survival rates and stress action resulting from a less rapid temperature change and varied D.O. levels. These fish did not show signs of stress as soon as the severely shocked fish in the 
first tests, but demonstrated signs' of stress at about the same temperature level.

21. Fish which had reached high temperatures $\left(26.7^{\circ} \mathrm{C}\right)$ successfully in earlier tests were subjected to small temperature increases at the high end of the temperature range scale after a small sudden temperature jump of several degrees. Temperature variations were preceded by a short period ( 2 hours) of stabilization at an intermediate level of about $26^{\circ} \mathrm{C}$. The D.O. was varied for comparison. It was determined that latent effects of rotenone had not affected the fish in the first shipment because water from one of the ponds which had been treated was used in this test. Fish reactions, temperatures, and D.0. levels for this first series of tests are shown in Plate 7.

22. One test was made to determine the effect of a sudden temperature change while the fish were under sedation (quinaldine) maintaining D.O. levels similar to those of the rearing ponds. Reactions are indicated in Plate 8.

23. Two tests were conducted to determine the effects of salt with variable temperature rates and D.0. levels. Results are shown in Plate 9.

24. The reactions of the fish to raising the temperature through the entire temperature range while maintaining a high D.O. level were examined. Results are recorded in Plate 10.

25. The fish survival rate was examined during rapid temperature increases to as high as $24^{\circ} \mathrm{C}$ followed by a stabilization period of about 11 hours then a subsequent increase to Gatun Lake temperatures. Additionally, one test was performed with the addition of salt and one without salt, with varying D.O. Jevels.

26. The final two tests were performed under conditions which had previously been examined except that the rate of temperature change was decreased and crowded conditions such as would be experienced in the acclimation pool were simulated. Results of this last series of tests are shown in Plate 11.

Test conclusions

27. Based upon the preceding tests, the following conclusions were drawn: 
a. Fingerling white amur can withstand a temperature increase from 4 to $22^{\circ} \mathrm{C}$ in as little as 2 to 3 hours with no apparent severe stress.

b. The addition of approximately $3000 \mathrm{mg} / \mathrm{l}$ of salt to acclimation water appears to allow the fish to make the transition more easily than in fresh water.

c. The temperature at which the fish appear to begin stressing is approximately 23 to $24^{\circ} \mathrm{C}$ if the transition period is accomplished in less than 6 to 8 hours. This observation is based upon initial temperatures of approximately $4^{\circ} \mathrm{C}$.

d. The D.O. level in the water during acclimation is relatively unimportant if maintained at greater than $3 \mathrm{mg} / \mathrm{l}$. Higher D.O. levels (i.e., greater than $7 \mathrm{mg} / \mathrm{l}$ ) appear to be beneficial in expediting recovery from mild cases of stress, provide a calming effect, and also help keep the fish swimming near the bottom of the tank when the temperature is in excess of $21^{\circ} \mathrm{C}$.

e. A temperature adjustment period of approximately 12 hours is beneficial to the welfare of the fish at some temperature between 18 and $22^{\circ} \mathrm{C}$. Acclimation through the full differential of temperatures from 4 to $27^{\circ} \mathrm{C}$ is not possible over periods of time less than 24 hours without extreme stress.

f. A temperature increase, following the 12-hour stabilization period, from approximately 20 to $29^{\circ} \mathrm{C}$ can be successfully accomplished at a maximum rate of about $2^{\circ} \mathrm{C}$ per hour.

g. The recuperation of stressed fish may be expedited by quickly lowering the water temperature 2 to $4^{\circ} \mathrm{C}$.

h. Rotenone residues were apparently not present in the pond water during the first fish delivery; therefore, they were not a factor in the heavy losses experienced in the first shipment.

\section{The Successful Second Delivery}

28. Based upon test results, a successful method to acclimate white amur using a holding tank with controlled temperature and D.O. concentrations was devised. The acclimation system was built in an unused portion of an elementary school building in Paraiso, Canal Zone, and consisted of a water intake with pumps at the edge of the Panama Canal, two large water chilling units, and a 19,000-litre holding tank. A schematic 
drawing of the system is shown in Plate 12. The chilled water was pumped into the center of the tank, discharged over three surface weirs, and disposed of in nearby storm sewers. The pumps had the capability of completely exchanging the water in the tank in 1.25 hours. This provided sufficient flow-through to permit rapid adjustments of temperature and D.O. and enable disposal of fish wastes which could cause a harmful buildup of ammonia and carbon dioxide. The two water chillers, which had previously been used to air-condition the school, had the capacity to cool the raw water to as low as $14^{\circ} \mathrm{C}$. The temperature in the tank was controlled by monitoring with two digital readout temperature probes and running or not running the chillers to lower or raise the temperature in the tank, as needed. D.0. levels were monitored at three selected positions around the tank and controlled by bubbling gaseous oxygen into the chilled water line downstream of the chillers. In addition, several mechanical surface agitators were suspended over the tank to set up a current against which the fish could swim.

29. The actual acclimation of the second shipment of fish started when they departed Little Rock Air Force Base on the evening of 12 March 1978. A total of $790 \mathrm{~kg}$ of fish, approximately 190,000 fingerlings, were loaded into the transport truck in 15 tanks (each 380 litres), and the truck was driven aboard the C-130 aircraft. The water temperature in the fish tanks was approximately $13^{\circ} \mathrm{C}$, and oxygen was supplied from a liquid oxygen bottle mounted at the rear of the truck. The oxygen .. was valved out of the bottle in gaseous form and bubbled through the water. The oxygen supply was manually controlled throughout the flight. D.O. levels were monitored in an attempt to maintain a range of 4 to 8 $\mathrm{mg} / \mathrm{l}$. However, due to changes in cabin pressure, actual D.0. levels remained above $10 \mathrm{mg} / \mathrm{l}$.

30. The aircraft arrived at Howard Air Force Base in the Canal Zone in the early morning hours of 13 March.' After deplaning and administrative formalities, the truck was driven to the acclimation facility at Paraiso, a distance of about $20 \mathrm{~km}$ (Figure 4 ).

31. The transfer of fish from the truck to the holding tank (Figure 5) began when temperatures in both had equalized to $14.4^{\circ} \mathrm{C}$. All 


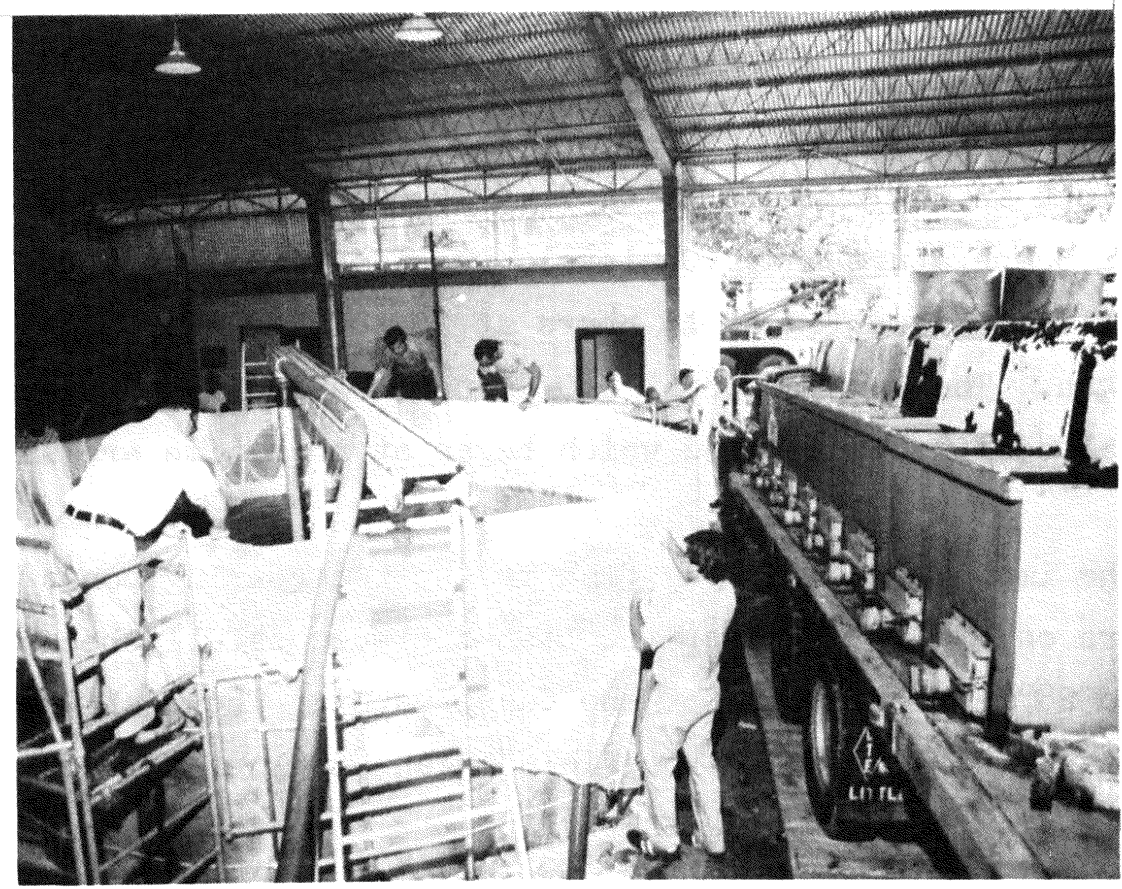

Figure 4. Fish holding tank constructed at Paraiso, Canal Zone, for the second shipment of fish. Transport truck is parked beside tank ready to be unloaded

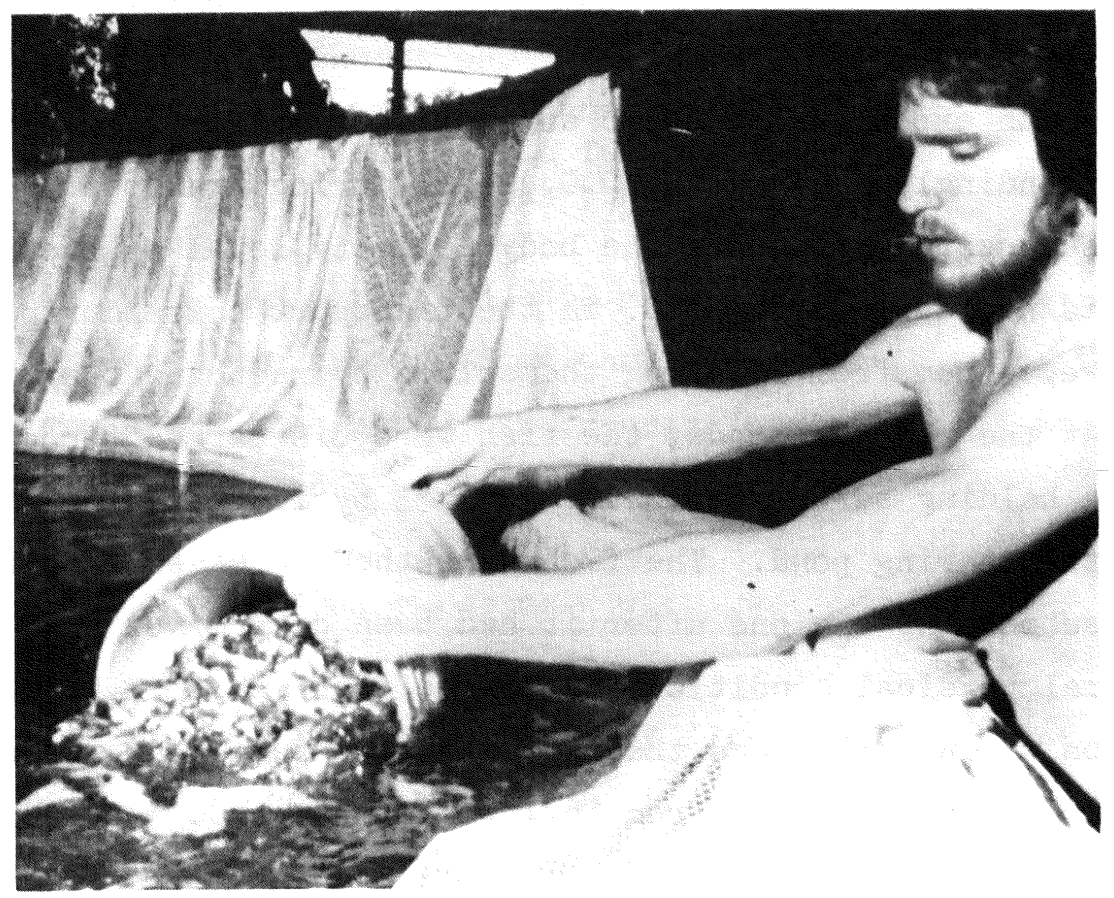

Figure 5. Transferring fingerlings of the second shipment from the truck to the fish holding tank 
fish had been moved into the tank by 1100 hours. Acclimation procedures were begun shortly thereafter by increasing the temperature in the tank gradually at a rate of $3^{\circ} \mathrm{C}$ per hour. At 1600 hours that afternoon, the tank water was $20^{\circ} \mathrm{C}$ and all fish were doing well. D.0. levels were maintained in the range of 4 to $7 \mathrm{mg} / \mathrm{l}$. Constant monitoring and recording of temperature and D.0. levels were initiated at 1600 hours when a stabilization period of 15 hours at 20 to $21^{\circ} \mathrm{C}$ and 4 to $6 \mathrm{mg} / \mathrm{l}$ D.O. was begun. The temperatures, D.O. concentrations, and remarks for the final acclimation period which began at that time are shown in Plate 13.

32. The implantation of the fish in the two rearing ponds began at 0800 hours on 15 March, after the fish had successfully been acclimated to the $28^{\circ} \mathrm{C} \pm$ temperature of the Canal water. The fish were netted out of the tank and carried to the field in an 850-litre fiberglass airtransportable fish box. Two boxes were used alternately and were moved from the holding tank to a helicopter pickup site $0.5 \mathrm{~km}$ away on a flatbed truck. They were then transported to the rearing ponds slung beneath a U. S. Army helicopter in eight sorties. (Figure 6). In the last six sorties, the fish were sedated with the tranquilizer, quinaldine. The sedative was employed after the second sortie in which a 20 percent loss was experienced due to an increase in water temperature which correspondingly lowered the D.O. level during transport. The quinaldine successfully reduced the body activity level of the fish such that they did not deplete the D.O. in the transport boxes during the flight and kept them from injuring themselves by reducing their physical activity. At the rearing ponds, the fish were discharged through PVC pipes into a holding screen enclosure ( 3 by 3 by $1.5 \mathrm{~m}$ ) which was floated in the rearing pond. The fish were then released from the enclosure by submerging one end after it had been determined that they were in normal physical condition. The time required to make such a determination was usually less than 20 minutes. Lake temperatures in the rearing pond areas varied from 26.1 to $28.3^{\circ} \mathrm{C}$ throughout the day of implantation.

33. The total number of fish lost during the acclimation period 


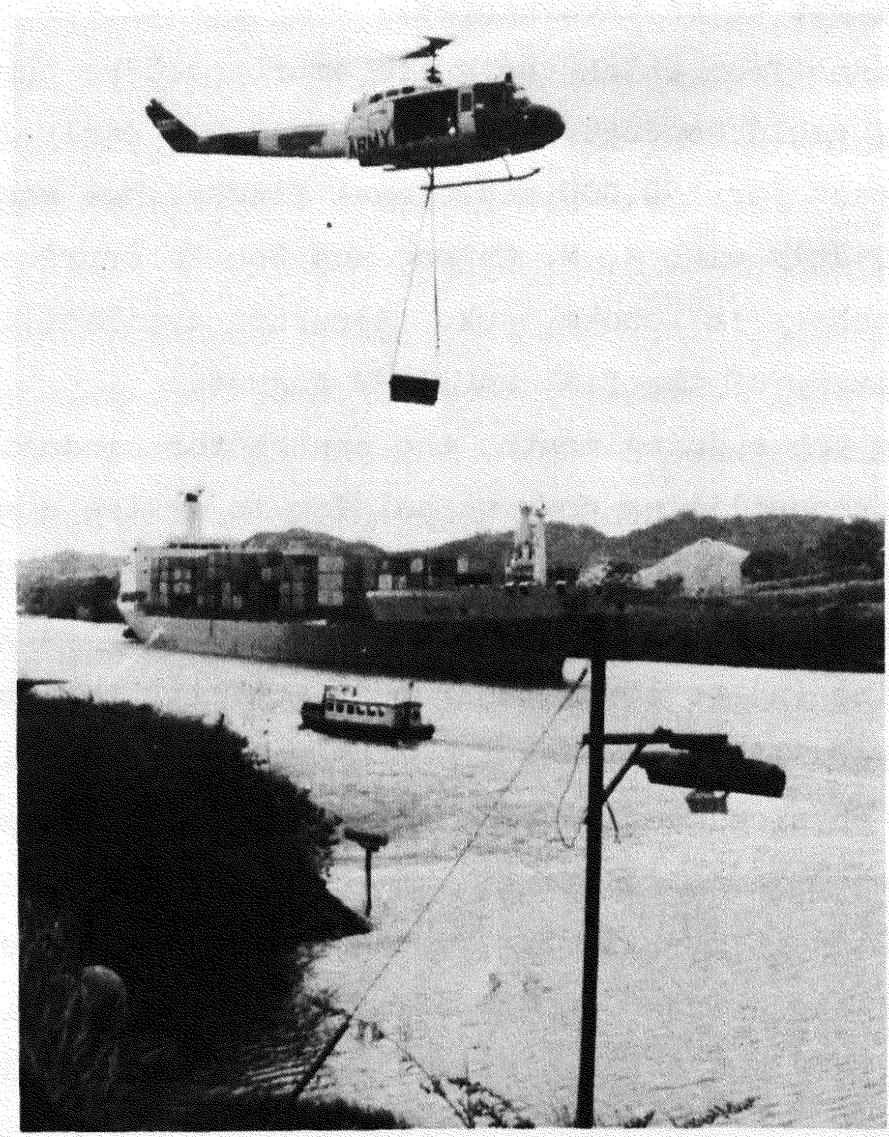

Figure 6. Aerial transport of the fish from the acclimation facility to the grow-out ponds

was less than 1000. An estimated 6850 more were lost during transportation to the field, more than half on the second sortie. The total loss from Arkansas to the Gatun Lake rearing ponds was slightly over 4 percent, about half as much as had been anticipated.

\section{The Third Fish Shipment}

34. In order to make up the loss of fish from the first shipment, Panama Canal Company management decided to import a third increment of fish during the July-August 1978 time frame. The first grow-out pond, Lake Calamito, was still separated from Gatun by the screens over the culvert under the railroad fill, and predator fish had not returned to 
Calamito. The initial fears that the screens might fail under rainy season flows turned out to be unwarranted.

35. The farms from which the white amur could be purchased reported that they would conduct the spring spawn in early June. Consequently, a contract for 150,000 additional fingerlings was negotiated and signed on 20 July with J. M. Malone and Son Enterprises and Leon Hill Catfish Hatchery in Lonoke, Ark. Aircraft availability necessitated putting off delivery of the fish until 22 August.

36. During the ensuing month, the contractor conducted extensive tests with the tranquilizing drug quinaldine to devise a method to enable the fish to pass through a temperature increase of $10^{\circ} \mathrm{C}$ without harm. Based upon these tests, the fish were transported in a weak solution of quinaldine (a) to lower their body activity to the point where they would use very little oxygen from the water; (b) to lessen the amount of their physical activity so that they would be less likely to injure themselves during transport; and (c) to produce an anesthesia which would dull their sensitivity to the temperature shock in going from the cold Arkansas water to the warm Canal Zone water. The tests showed that the fish could be introduced into the tropical system without the requirement of the expensive fish tempering facility used with the second shipment. One of the factors which swayed Panama Canal officials to try this method was that the contract specified that the fish had to be in the grow-out pond alive and healthy prior to their acceptance, which placed the responsibility for successful implantation directly on the contractor. In order to offset any loss that the contractor might experience before the determination that there were 150,000 live fish in the lake, the contractor shipped an extra 27,000 fingerlings.

37. As in the second delivery, the D.O. level of the water in the truck was maintained by entrainment of gaseous oxygen valved out of a liquid oxygen bottle mounted on the truck. At approximately 0530 hours on 23 August, the C-130 carrying the fish truck landed at Howard Air Force Base." By 0730 that morning, the truck had arrived at the edge of Lake Calamito and was ready to discharge the fish into the lake. To 
test the ability of the fish to make the transition from the transport truck water at $21^{\circ} \mathrm{C}$ to the lake water of $28^{\circ} \mathrm{C}$, approximately $30 \mathrm{fish}$ were placed in a $1-f t^{3}$ wire enclosure in the lake and observed for more than half an hour (Figure 7). As the effect of the quinaldine wore off, the fish became more active but demonstrated no temperature shock. The fish were "shot" down a 4-in.-diam pipe from the truck into a 3- by 3by $1.5-m$ screened enclosure which was floated in the lake (Figure 8 ). Discharging the fish into this enclosure enabled a determination to be made that the fish were well prior to their release into the lake.

Three such enclosures were used, each containing about 60,000 fish. As each enclosure was filled, it was towed out to a raft in the midale of the lake (Figure 9) and another brought up to the bank to be filled. After approximately 45 minutes, it was decided that the fish were completely acclimated to their new environment, and the cages were tipped up on end and the fish "herded" out into the lake. Less than 100 fish

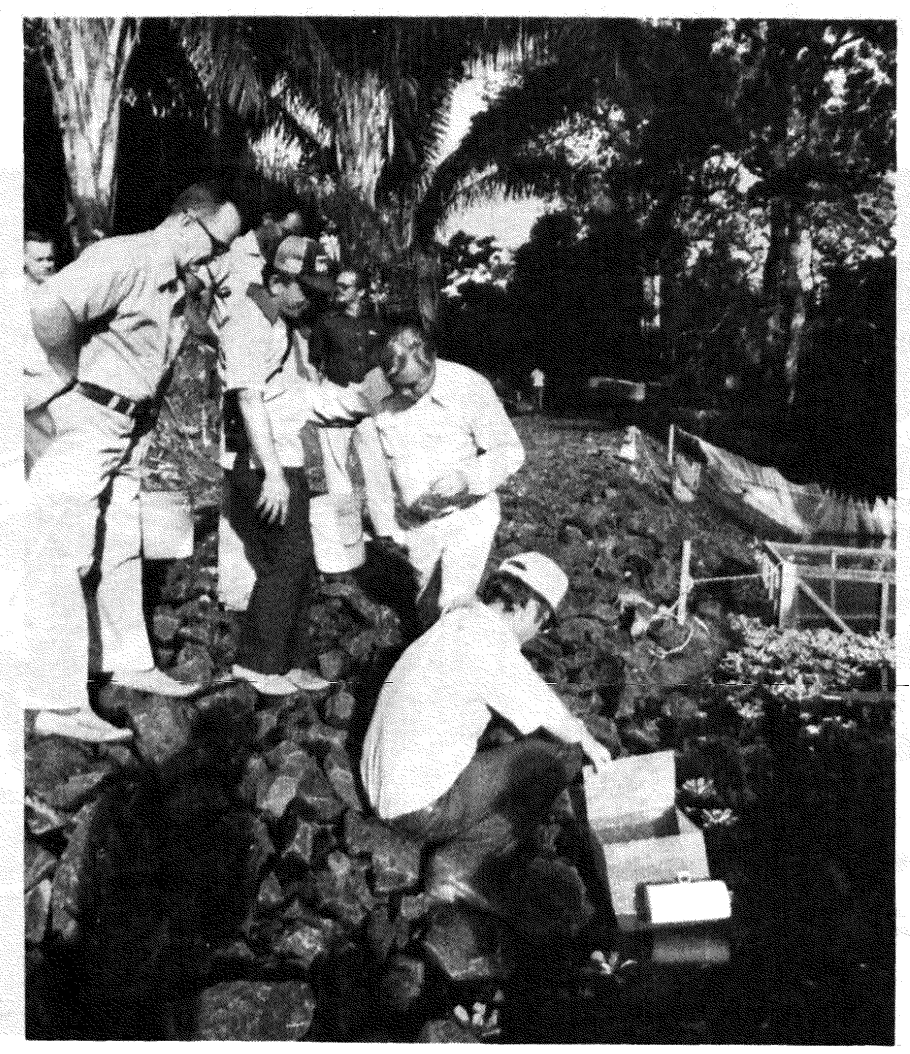

Figure 7. Fish from the third shipment being placed in a $1-f^{3}$ screened cage and observed 


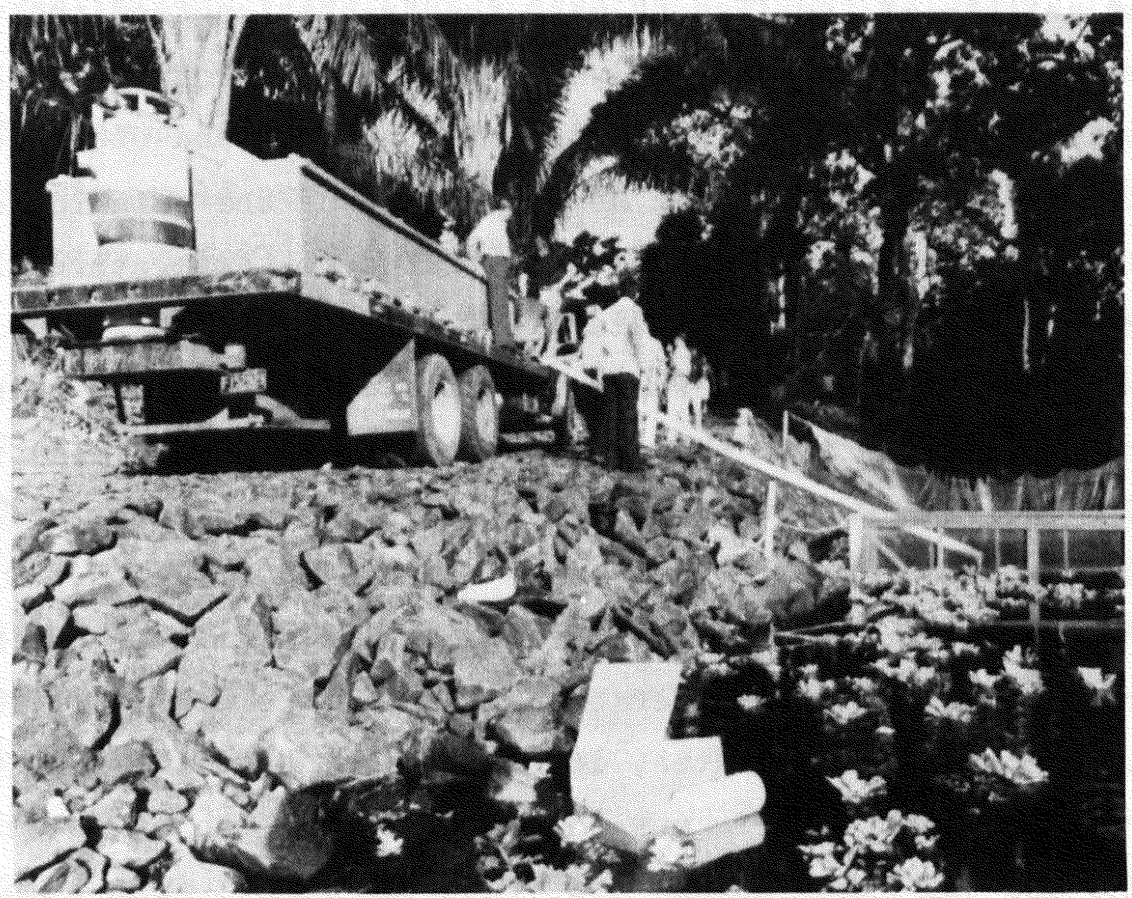

Figure 8. Depositing the third shipment of fish into the grow-out pond

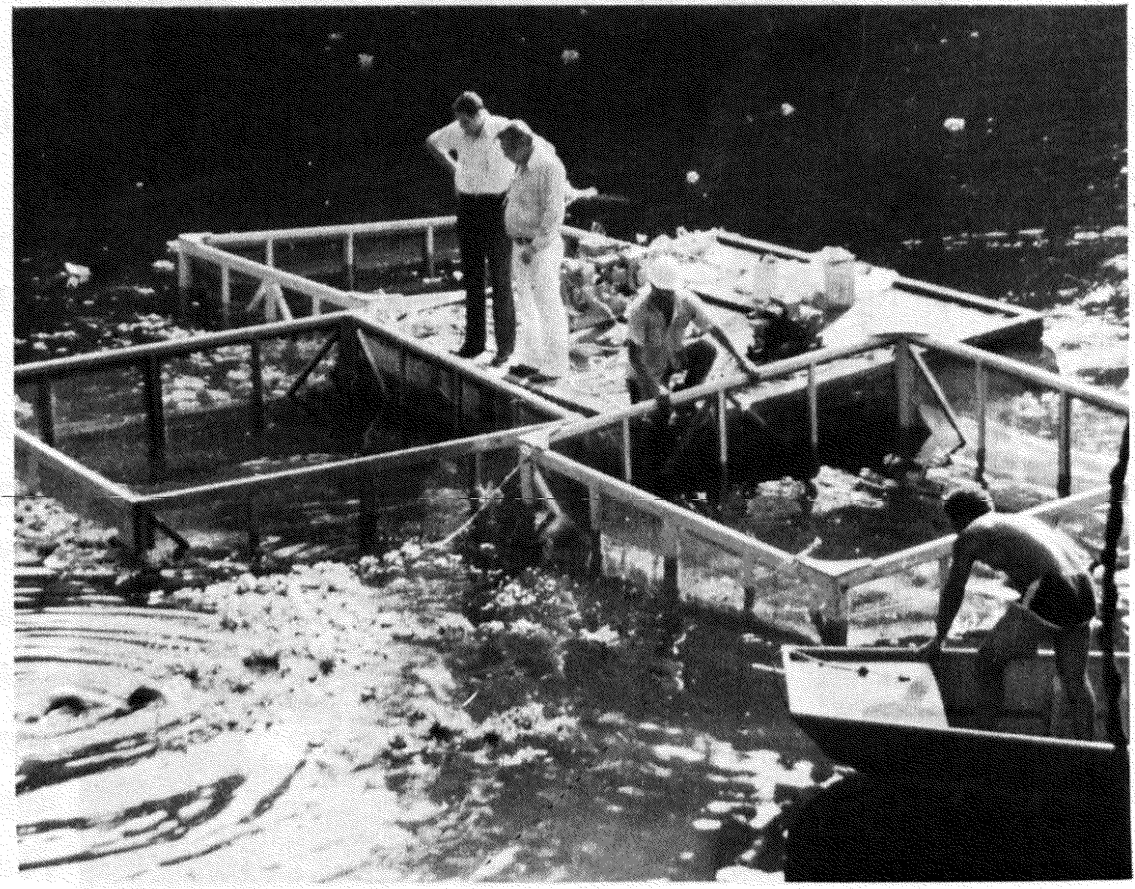

Figure 9. Observation of the fish from the third shipment in the screened enclosure for 45 minutes revealed that they suffered no temperature shock in going from the cold transport water to the warm lake. (If stress had developed, air compressors were standing by to begin aeration under the enclosure to revive the fish.) 
were lost, which is an insignificant percentage for such a large fish transport operation.

\section{Release of the Fish to Gatun Lake}

38. After the successful implantation of the second shipment of fish in March 1978, a monitoring program was established to check fish growth rate and consumption of hydrilla. Evidence of the feeding activities of the fish were observed within 2 months after introduction. Large amounts of floating hydrilla stems from which the leaves had been stripped were beginning to collect near the dike, creating a cleaning problem at the screen over the pipe through the dike.

39. In mid-July, large schools of fish were observed swimming along the dike. One of them was successfully caught on 11 July in order to measure its weight and size. It weighed exactly 2 Ib and was 16 in. long (Figure 10). At that point, a decision had to be made as to whether or not to release the fish into Gatun Lake or hold them in the grow-out ponds longer. In order to demonstrate their capabilities, it was decided to keep them in the grow-out ponds until they had consumed all the hydrilla.

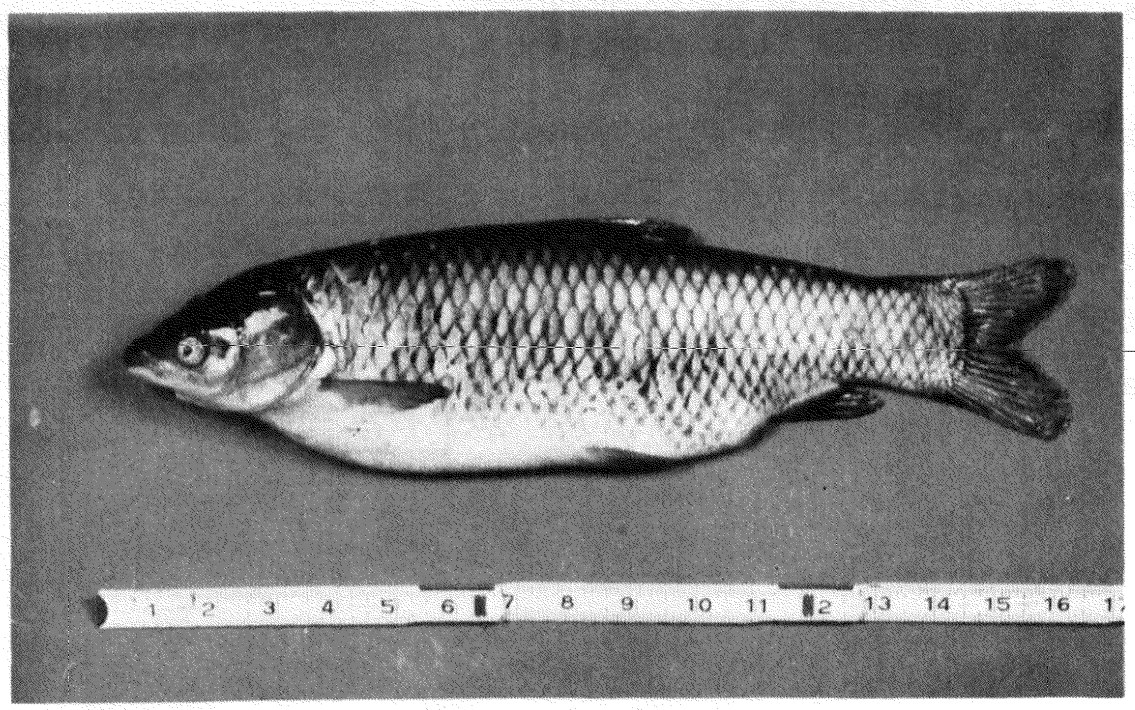

Figure 10. White amur fish from second delivery approximately 4 morths after introduction to grow-out pond. Weight, $2 \mathrm{lb}$; length, 16-1/4 in. 
40. Over the weekend of 5 and 6 August, increased precipitation coupled with the high amounts of hydrilla pieces which had been torn loose by the fish created sufficient blockage of the culvert screen that water overtopped the dike. It was discovered on Tuesday morning, 8 August, that a gap had been eroded in the dike about $50 \mathrm{ft}$ wide and down to about $4 \mathrm{ft}$ below Gatun Lake level. Consequently, the fish had been released. Estimates of the biomass of hydrilla in Laguna indicated that there was less than 1 acre of plants left out of the initial 70 acres. Because of the elimination of the hydrilla, breaching of the dike would have been necessary within the next week by mechanical means anyway; however, nature did the job somewhat early and at no cost.

41. As of the writing of this report, the third shipment of fish has been in Lake Calamito for about 3 months. None of them has been sighted since their introduction, and there are no strong indications of feeding activity; however, it is expected that they will have con- . sumed the hydrilla in the pond by mid or late January. When that has been positively established, the fish will be released into Gatun Lake.

42. With the release of the third shipment, Gatun Lake will have an estimated white amur population of 350,000. To evaluate the effect of the fish on the hydrilla, plant biomass will be monitored on an annual basis with infrared photography.

43. The Panama Canal Company plans to begin a stocking program in FY 1981 to introduce 25,000 fish annually into the lake to maintain a sufficient population to bring about an effective, lasting control of the hydrilla. It is anticipated that the stocking level may need to - he adjusted as more knowledge is gained on the efficacy of the white amur as a biological control agent of submerged macrophytes. 


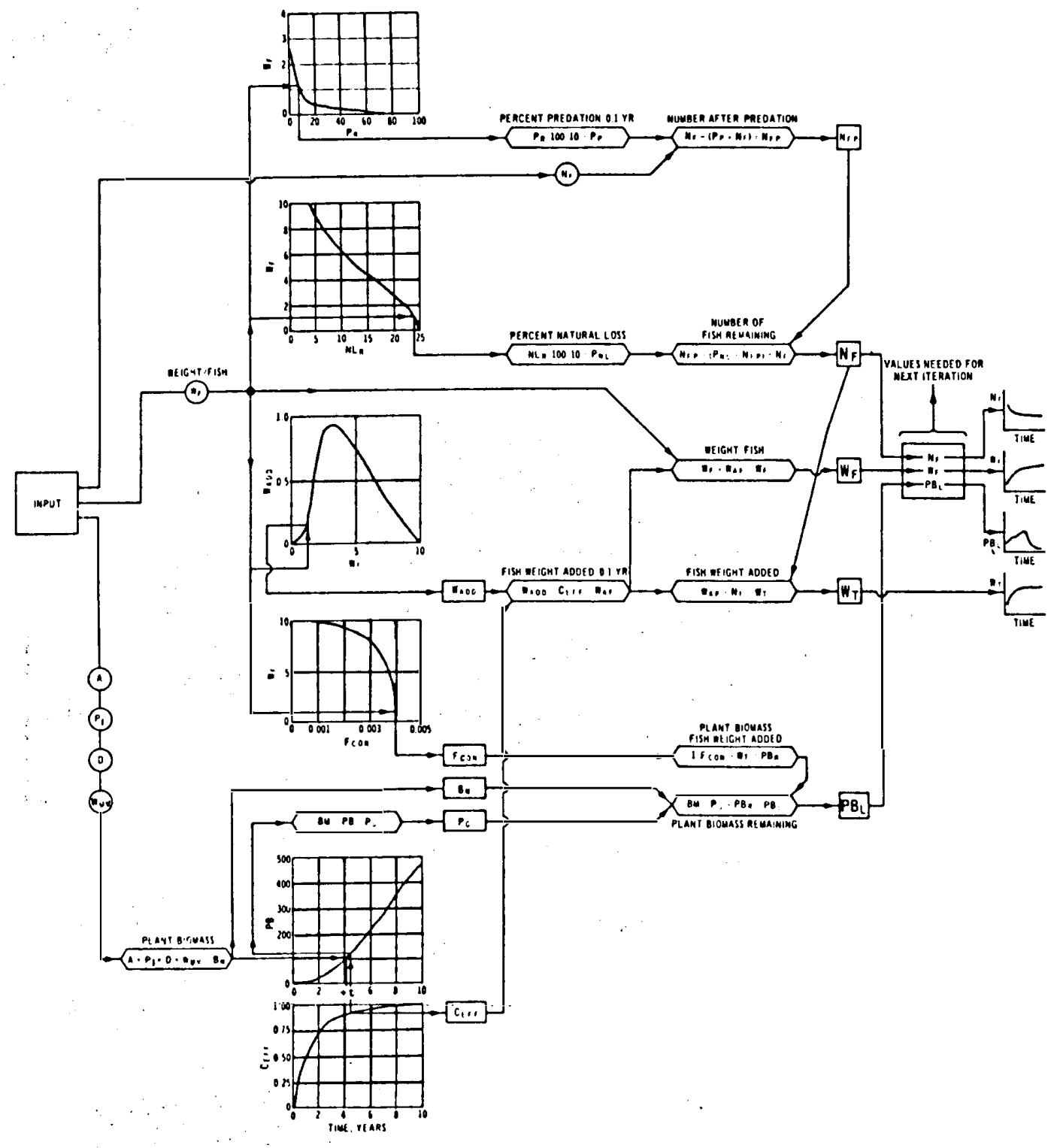

WHITE AMUR STOCKING RATE MODEL 


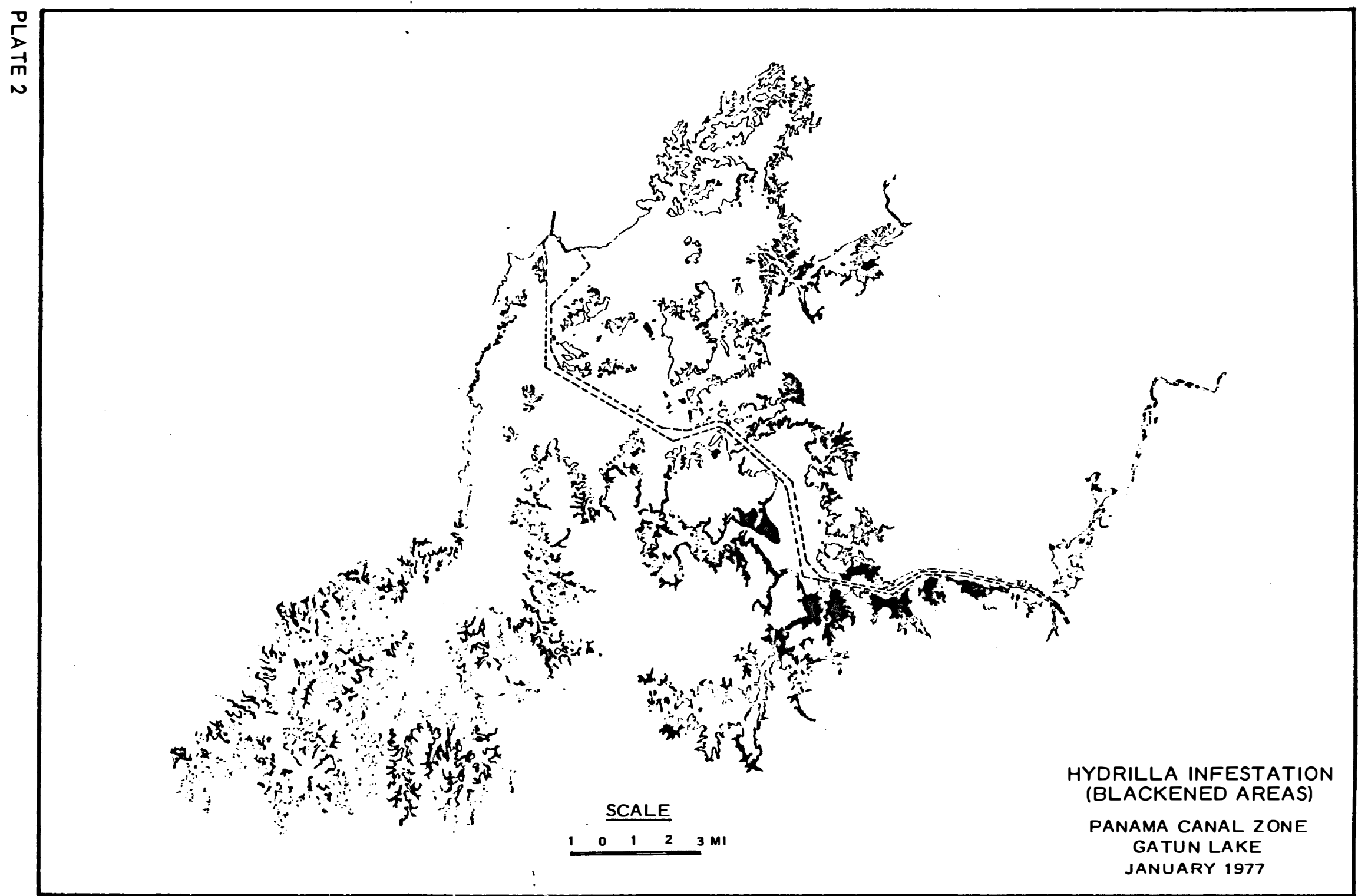




$$
q
$$




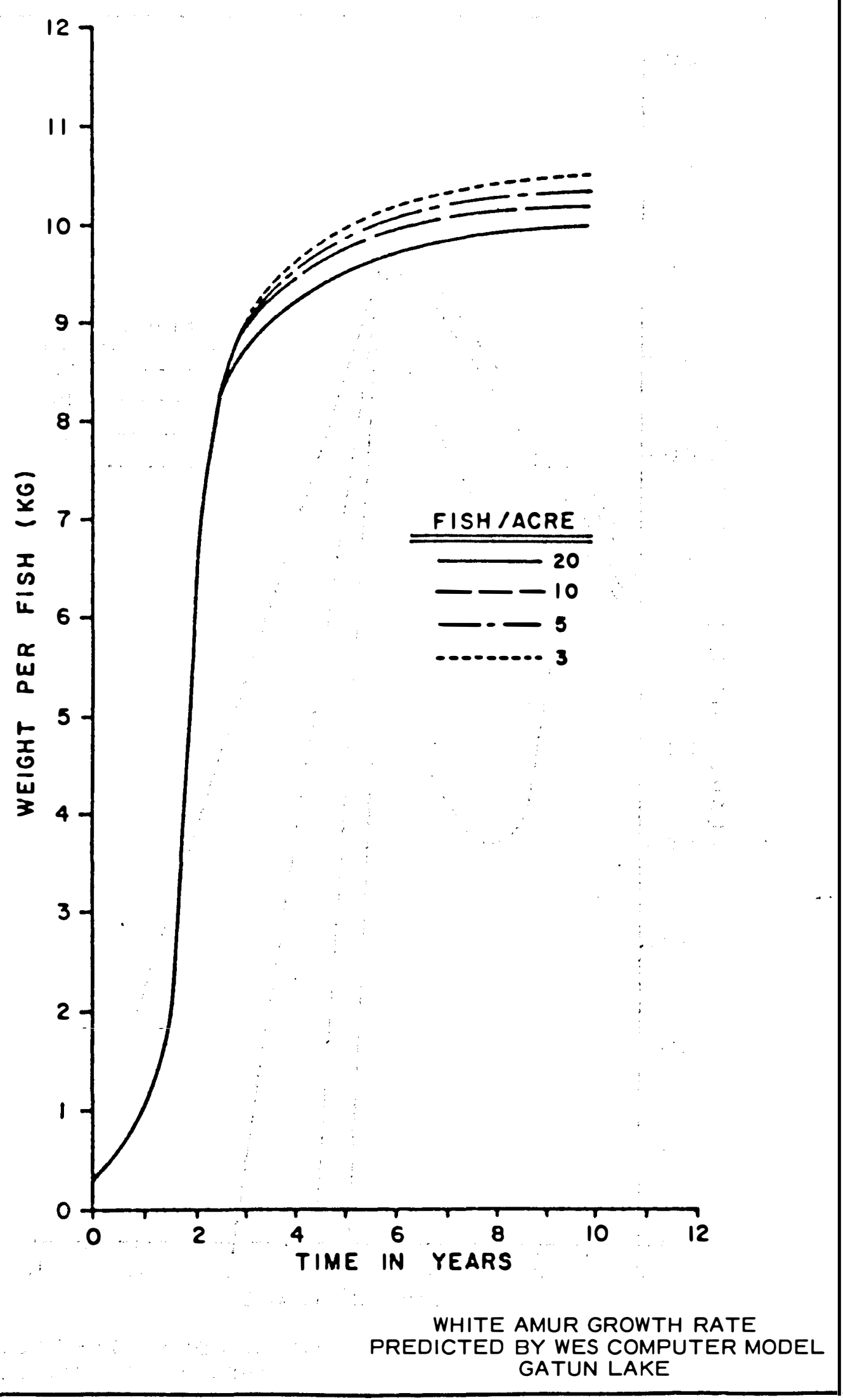




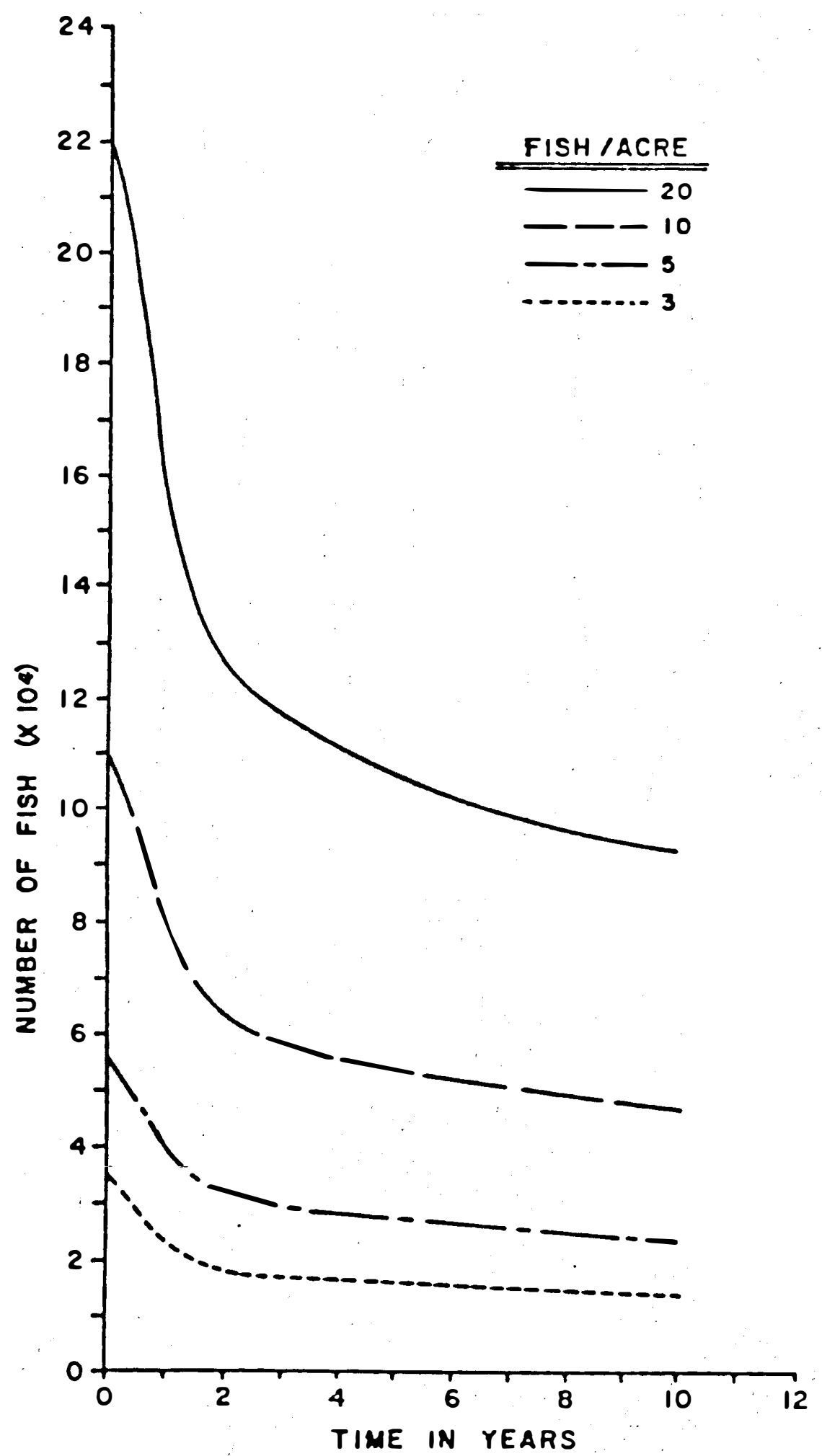

WHITE AMUR MORTALITY RATE PREDICTED BY WES COMPUTER MODEL GATUN LAKE 


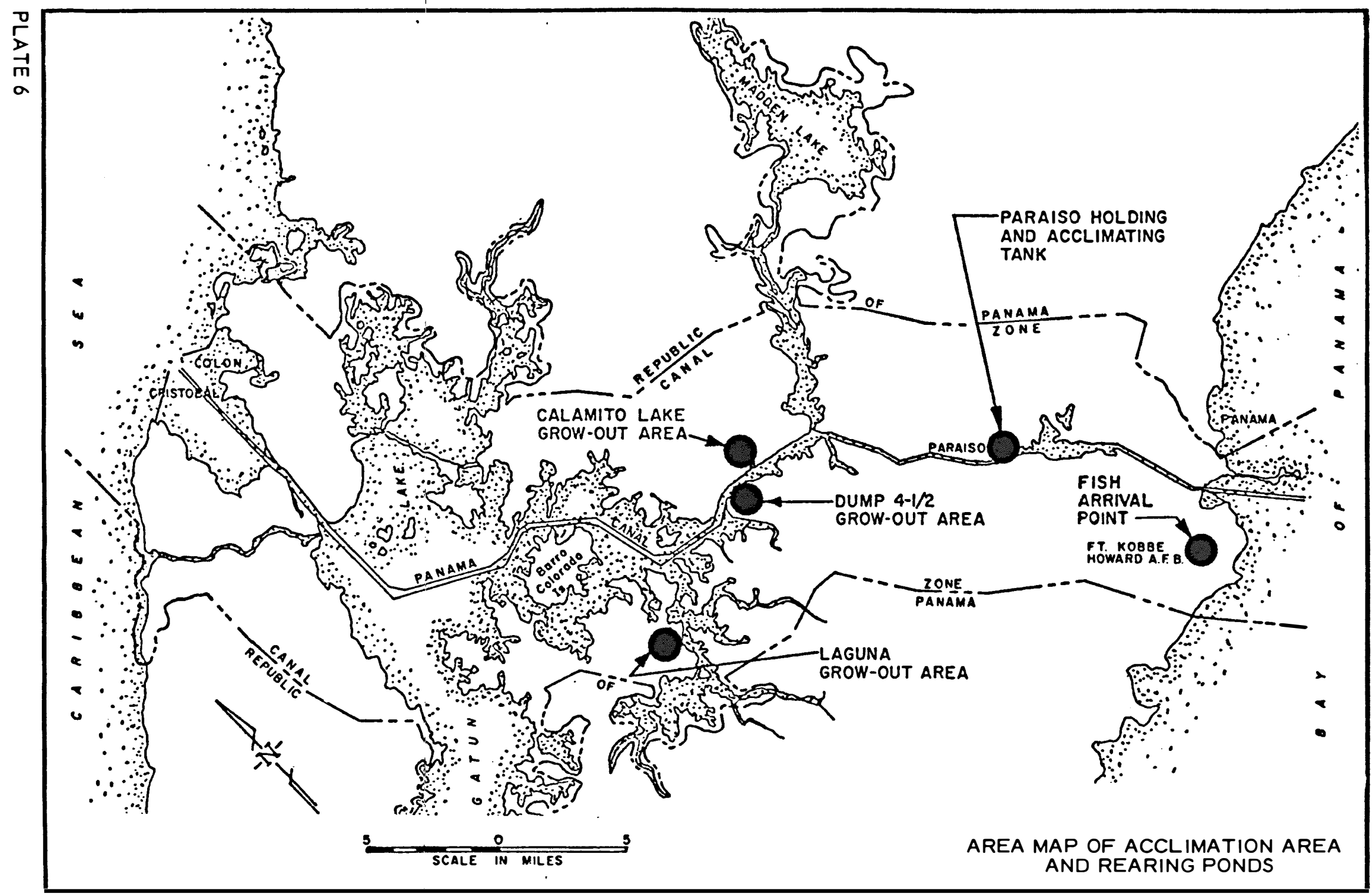




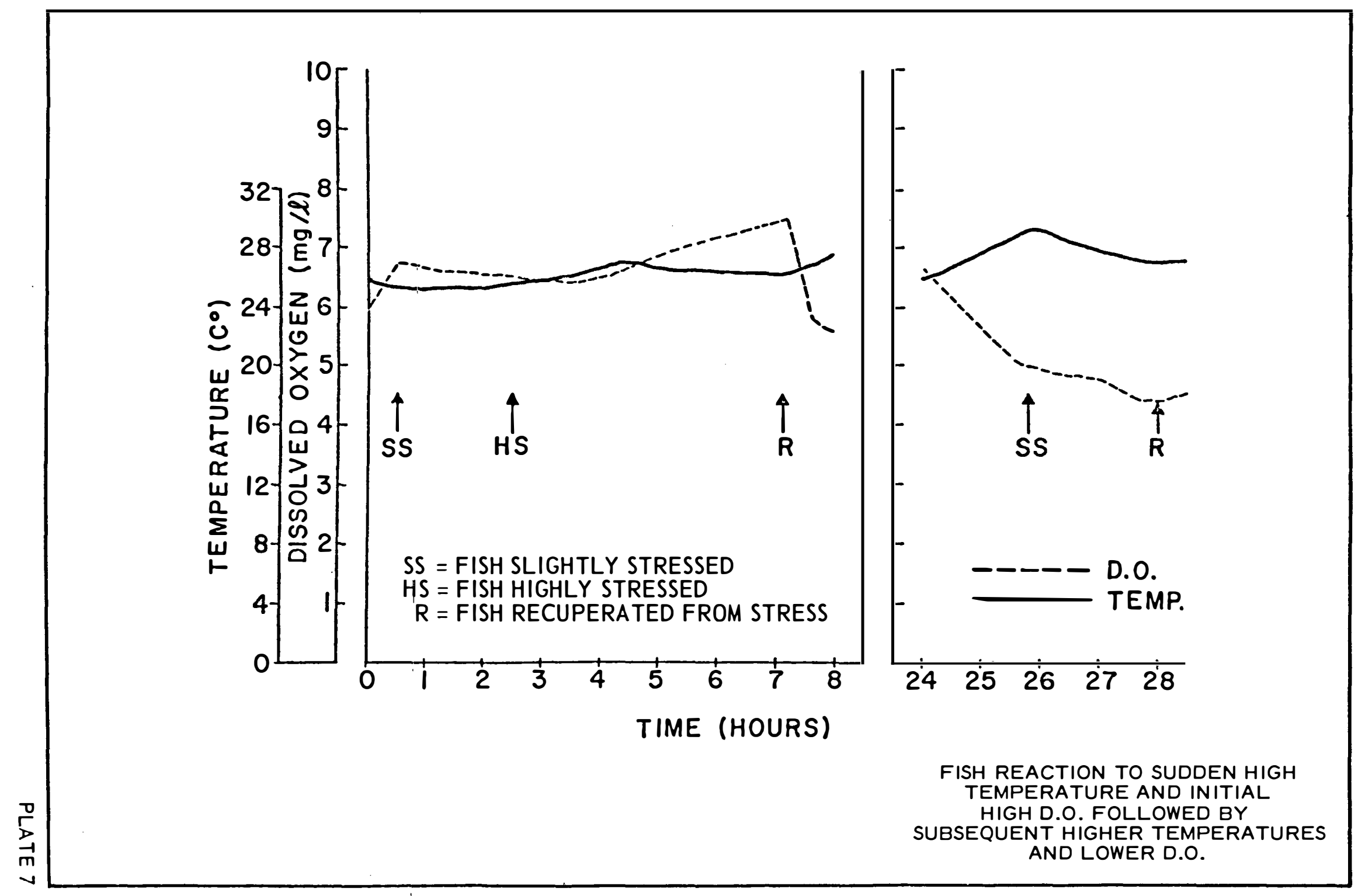




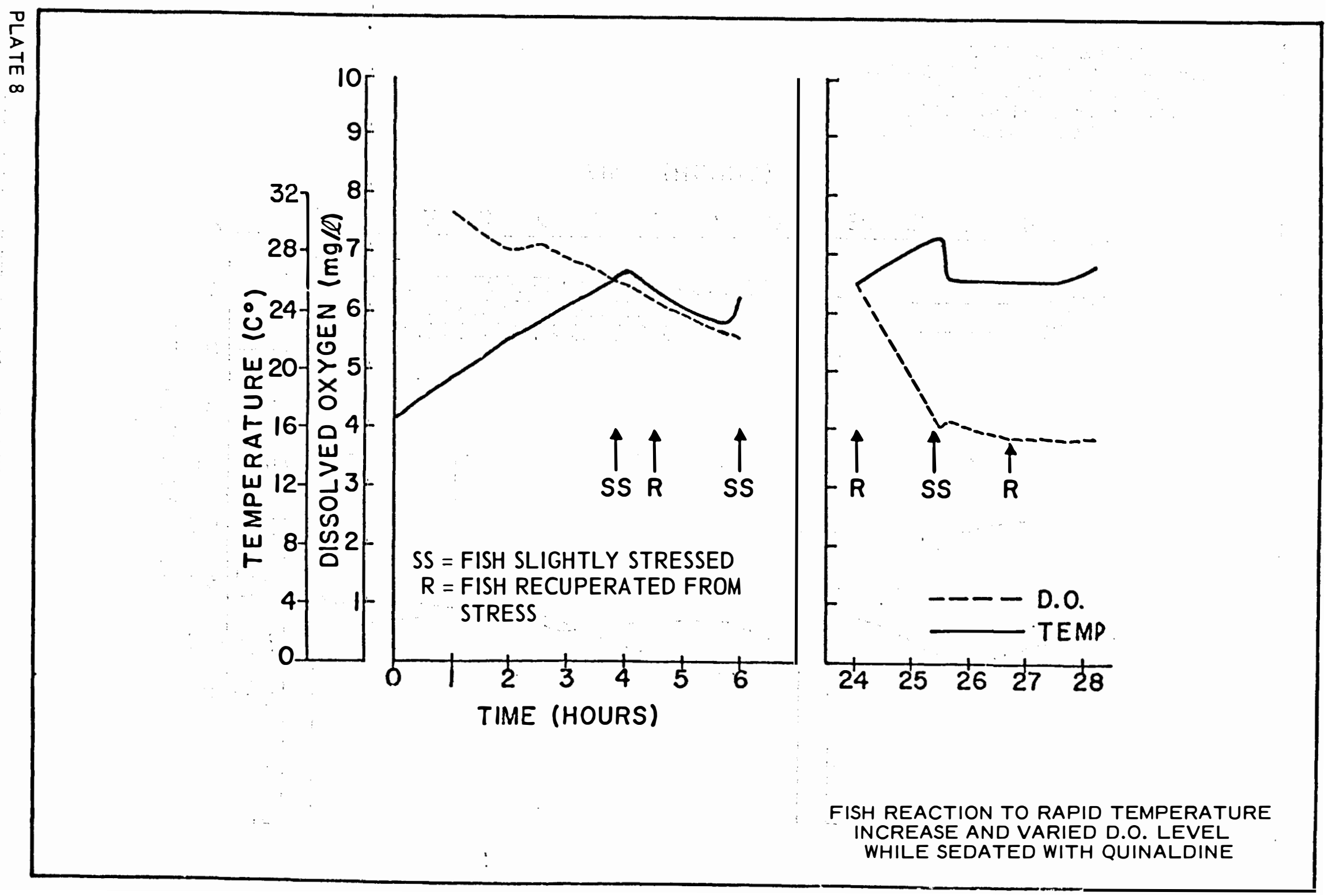




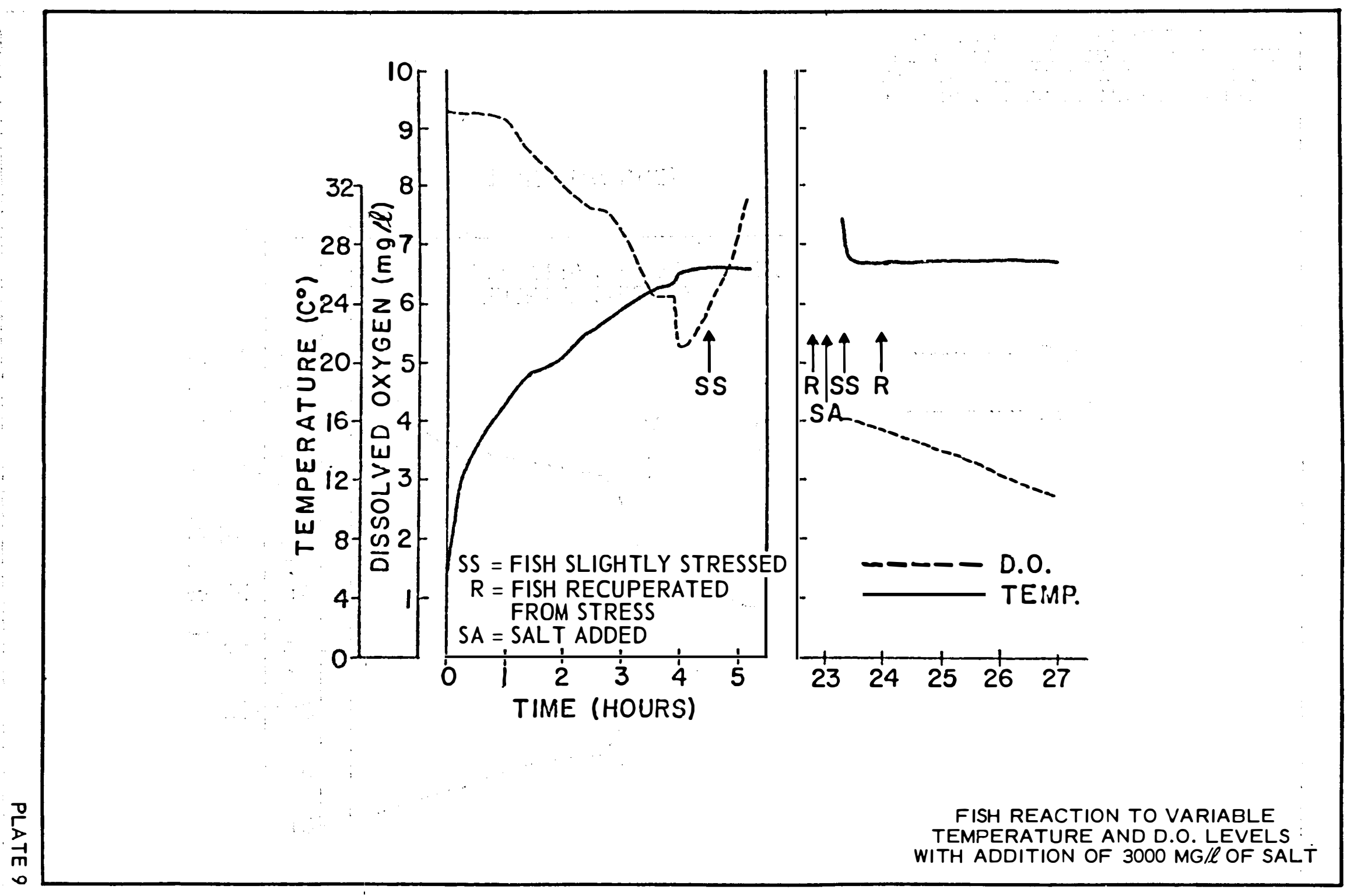




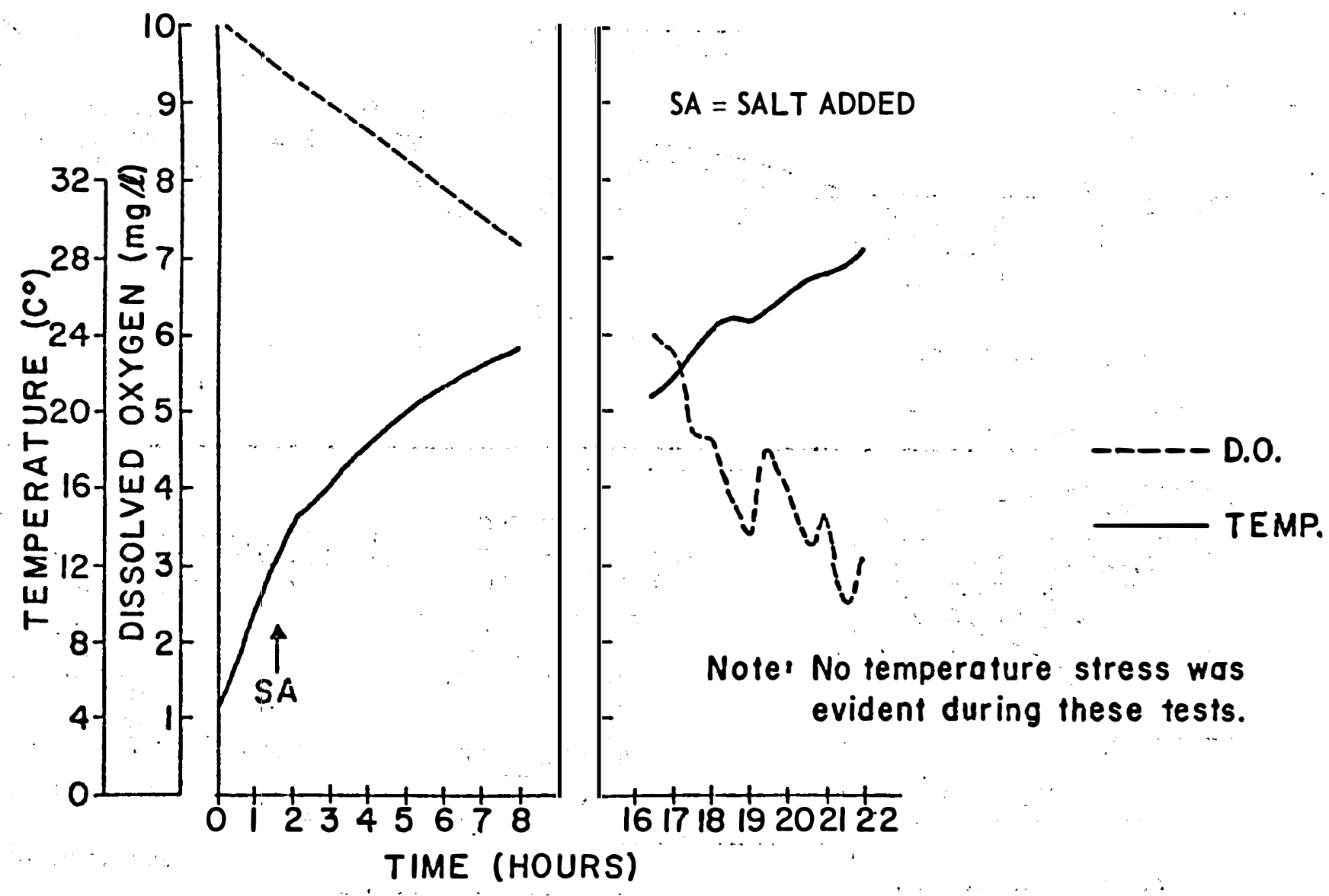




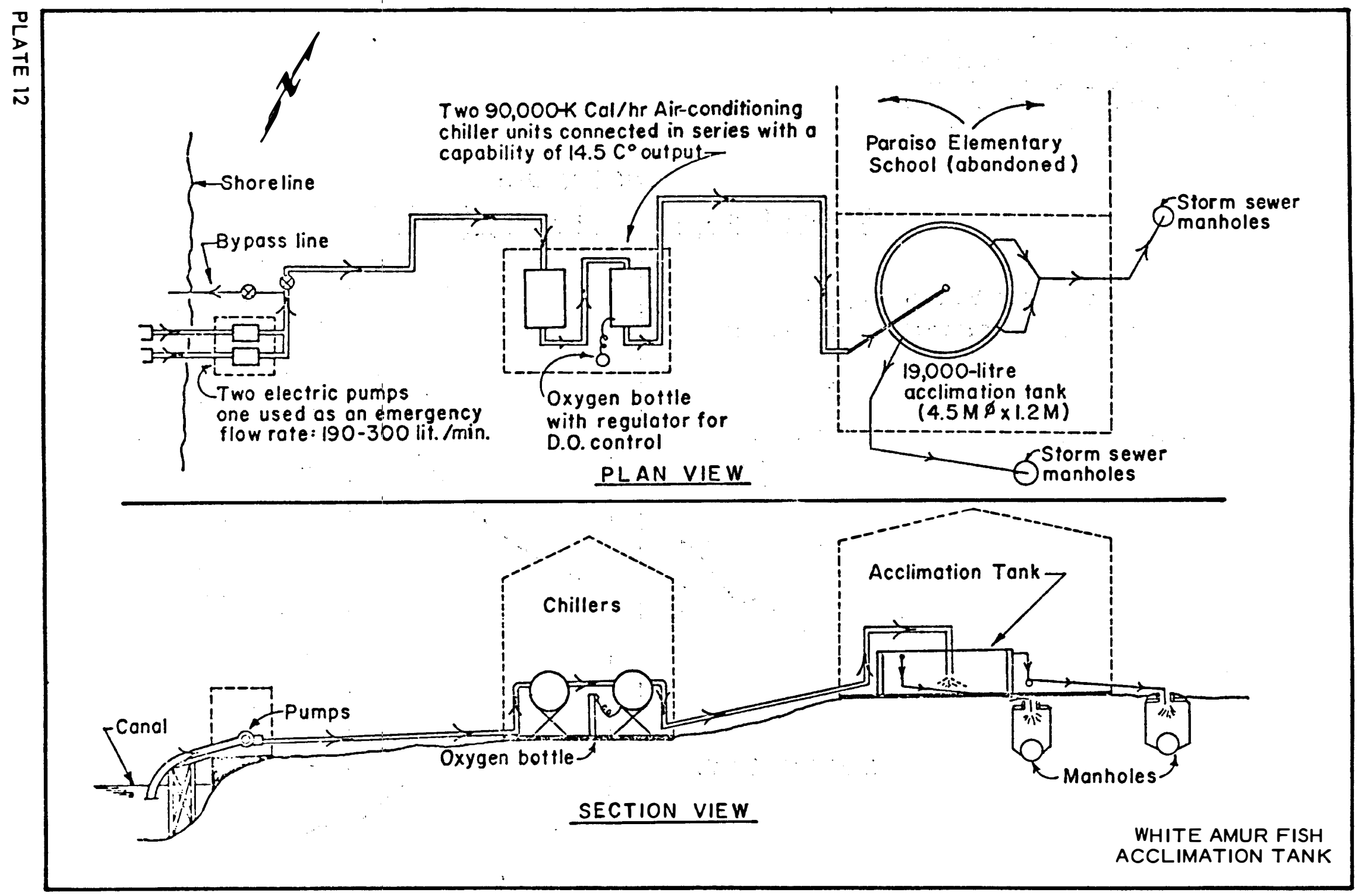




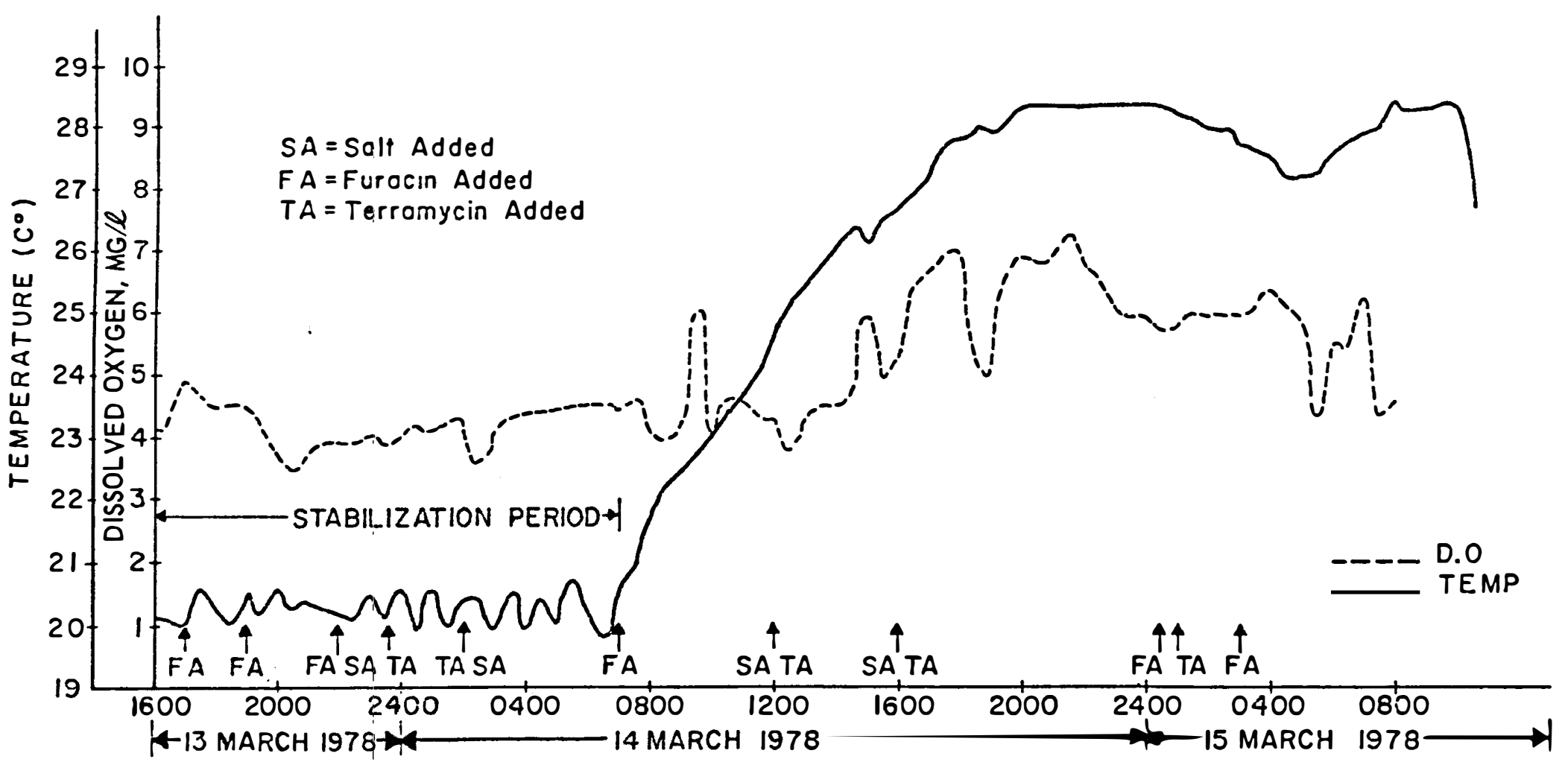

$\frac{7}{5}$ 